\title{
Burnout and Stress Measurement in Police Officers: Literature Review and a Study With the Operational Police Stress Questionnaire
}

\author{
Cristina Queirós ${ }^{1 *}$, Fernando Passos ${ }^{2}$, Ana Bártolo ${ }^{3}$, António José Marques, \\ Carlos Fernandes da Silva ${ }^{5}$ and Anabela Pereira ${ }^{5}$
}

${ }^{1}$ Faculty of Psychology and Education Sciences, University of Porto, Porto, Portugal, ${ }^{2}$ Psychology Unit of the Portuguese National Police, Lisbon, Portugal, ${ }^{3}$ Center for Health Technology and Services Research (CINTESIS), Department of Education and Psychology, University of Aveiro, Aveiro, Portugal, ${ }^{4}$ School of Health of the Polytechnic of Porto, Porto, Portugal, ${ }^{5}$ Department of Education and Psychology, University of Aveiro, Aveiro, Portugal

Research has demonstrated that policing is a stressful occupation and that this stress has a negative impact on police officers' mental and physical health, performance, and interactions with citizens. Mental health at the workplace has become a concern due to the costs of depression, anxiety, burnout, and even suicide, which is high among police officers. To ameliorate occupational health, it is therefore crucial to identify stress and burnout levels on a regular basis. However, the instruments frequently used to measure stress have not valorized the specificity of policing tasks. This study aims to: (i) conduct a literature review to identify questionnaires used to assess occupational stress and burnout among police officers; (ii) analyze the psychometric characteristics of a Portuguese version of Operational Police Stress Questionnaire (PSQ-Op); and, using the PSQ-Op and other questionnaires, (iii) to identify operational stress, burnout, and distress levels among Portuguese police officers. The literature review identified 108 studies which use a multiplicity of questionnaires to measure burnout or occupational stress among police officers, but few studies use specific police stress questionnaires. Sample sizes were mostly below 500 participants and studies were mainly developed in the last decade in the USA and Brazil, but also in another 24 countries, showing the extent of the interest in this topic. This study applied to 2057 police officers from the National Portuguese Police, a force policing urban centers, and used the PSQ-Op, as well the Spanish Burnout Inventory and the Kessler Psychological Distress Scale. The results show that the psychometric properties of the Portuguese version of PSQ-Op are adequate. Factorial analysis revealed two dimensions defined as social and work issues, which were associated with measures of distress and burnout. Fit indices suggested a second-order solution called operational police stress. Overall, and considering the scale range of each questionnaire, the results showed moderate values of operational stress, distress, and burnout. However, considering their cut-off points, $85 \%$ of the sample presented high operational stress levels, $11 \%$ critical values for burnout, and $28 \%$ high distress levels, with $55 \%$ of the sample at risk of a psychological disorder. These results reinforce the need to prevent stress and to invest in police officers' occupational health.

Keywords: burnout, distress, operational stress, police officers, questionnaire validation 


\section{INTRODUCTION}

According to recent systematic reviews, being a police officer seems to be a highly demanding and stressful occupation, due to the current characteristics of modern societies. For a police officer, those characteristics include: the uncertainty and danger related to the permanent threat of terrorist attacks, the increase of violence with firearms in urban areas, low human and material resources, team or supervision difficulties, criticism from citizens and society, and lack of understanding from family or friends (Cumming et al., 1965; Webster, 2013; Magnavita et al., 2018; Purba and Demou, 2019). Numerous studies have tried to map police officers' stress and its sources, a topic highlighted in the 1980s by the NIOSH technical report (Hurrell et al., 1984), and in the 1990s by Norvell et al. (1993), whose study focused on the influence of gender differences on law enforcement officers. Brown and Campbell (1994), Violanti and Aron (1995), and Stinchcomb (2004) also studied the sources of policing stress. However, this topic has attracted more interest in the last decade, with studies developed, for example, by Hickman et al. (2011), Luceño-Moreno et al. (2016), and Violanti et al. (2017), all of whom continue to identify police officers' stress sources and its negative impact on police officers' health and job performance. More recently, Baldwin et al. (2019), Wassermann et al. (2019), and Ermasova et al. (2020) have contributed to the study of police officers' stress and psychological/physical health. Related studies have focused more specifically on occupational stress (e.g., Agolla, 2009; Maran et al., 2015; Gutshall et al., 2017; Johnson et al., 2019), while others have investigated police officers' burnout (e.g., Aguayo et al., 2017; Adams and Mastracci, 2019).

This has led to an increasing interest in police officers' psychological well-being, with researchers emphasizing the negative impact of working with negative social situations, such as crime and death (Henry, 2004), which can affect mental health and elicit physical fatigue, compassion fatigue, and even moral suffering (Basinska and Wiciak, 2012; Papazoglou, 2016; Papazoglou et al., 2017, 2020; Violanti et al., 2019). Moreover, studies have concluded that job stress has consistently increased among police officers in the last decade, and this chronic job stress negatively affects both the person and the organization. Individually, it leads to poor mental health (Baldwin et al., 2019; Castro et al., 2019), work-family conflict (Griffin and Sun, 2018), non-adaptive coping strategies and job stress (LeBlanc et al., 2008; Zulkafaly et al., 2017), emotional labor (van Gelderen et al., 2007), burnout (Pines and Keinan, 2005, 2007; Rosa et al., 2015), and even suicide (Violanti, 1996; Blazina, 2017; Costa et al., 2019; Grassi et al., 2018). Organizationally, it affects performance (Shane, 2010; Bertilsson et al., 2019; Kelley et al., 2019), counterproductive work behaviors (Smoktunowicz et al., 2015), and inappropriate interactions with citizens, such as the use of excessive force (Neely and Cleveland, 2011; Mastracci and Adams, 2019).

A number of news sources have recently reported that France ${ }^{1}$ faces an increasing number of police officers committing suicide, especially after the intense work due to the "yellow vests/jackets"

\footnotetext{
${ }^{1}$ https://apnews.com/aa2ac2c871a349ecbdb98313b644634b (August 2019).
}

manifestations, while Spain ${ }^{2}$ and Portugal $^{3}$ have also experienced several suicides of police officers, which motivated police officers to demonstrate in the streets and show their anger with job conditions in France ${ }^{4}$ and Portugal ${ }^{5}$. Hard working conditions and colleagues' suicides elicit continuous suffering and psychological pain that affects police officers, their families, and their tasks in important domains of urban life: safety and security. Additionally, stressful situations can increase the use of antidepressants, anxiolytics, or tranquilizers to alleviate psychological suffering, with Portugal being one of the countries where this increased use is the highest in Europe (OECD, 2019), suggesting the need to invest in stress and anxiety prevention and in occupational health.

Despite the increased number of studies analyzing occupational stress and burnout among police officers, researchers frequently use measurement instruments developed for other professional groups which do not apply to the specificities of police tasks, including emotional labor and physical risks. This study aims to: (i) conduct a literature review to identify questionnaires that have been used to assess occupational stress and burnout among police officers; (ii) analyze the psychometric characteristics of a Portuguese version of Operational Police Stress Questionnaire (PSQ-Op), developed by McCreary and Thompson (2006), to assess the specificities of job stress among police officers; and, using the PSQ-op and other questionnaires, (iii) identify operational stress, burnout, and distress levels among Portuguese police officers.

Regarding burnout and occupational stress measurement among police officers, in the 1970s Freudenberger (1974) and Maslach (1976) identified the symptoms of burnout and defined burnout syndrome as a psychological disorder triggered by chronic exposure to work stress. Burnout has attracted considerable interest in the scientific community and has become a concern for workers, being recognized as a serious professional hazard and a psychosocial risk at work. The definition presented by Maslach and Jackson (1981) seems to be the most consensual, and states that burnout is a three-dimensional syndrome that affects workers whose job tasks are mainly related to helping and delivering care or services to other persons. Burnout is expressed by emotional exhaustion (feeling fatigued and powerless to provide more support to others), depersonalization (showing a disengaged, cynical, cold, and unsympathetic attitude toward persons at work, especially those who seek help or ask for services), and feelings of low professional achievement (feeling personal and professional inadequacy, and having a higher likelihood of committing errors during job tasks). Later, as a result of continuous research on burnout (Maslach and Leiter, 2016, 2017; Maslach, 2017) stated that burnout occurs more

\footnotetext{
${ }^{2}$ www.facebook.com/zerosuicidiopolicial/ (January 2020) and https //www.elespanol.com/reportajes/grandes-historias/20170909/245476036_0.html (September 2017).

${ }^{3}$ https://www.publico.pt/2019/07/17/sociedade/noticia/sindicatos-queremministerio-publico-investigue-suicidios-policia- 1880178 (July 2019).

${ }^{4}$ https://www.euronews.com/2019/10/02/thousands- of-french-police-protestfor-better-working-conditions-and-answer-to-high-suicid (October 2019). ${ }^{5}$ https://sicnoticias.pt/pais/2019-11-21-Dia-de-manifestacao-de-policias-emLisboa-sob-olema-tolerancia-zero (November 2019).
} 
frequently among professionals who work with other persons, especially as service providers where, over the years, they must respond to the client's demands in a society increasingly based on service exchanges, which elicits job stress.

Burnout appears as a response to chronic job stress (Schaufeli, 2017) and has become an epidemic phenomenon with costs for workers and organizations, which is a concern that has been repeatedly highlighted by the European Agency for Safety and Health at Work (EU-OSHA, 2018), namely with its "Healthy Workplaces" campaign. Moreover, several key organizations have reinforced the importance of burnout in modern society. On 10 October 2017, the World Health Organization (WHO) defined mental health in the workplace as the theme for World Mental Health Day, highlighting job stress among specific professional groups, and in 2019 the WHO defined suicide prevention as the theme $e^{6}$, alerting the public to the risk of suicide among specific professional groups. In September 2018, the European Foundation for the Improvement of Living and Working Conditions (EUROFOUND, 2018) published the report "Burnout in the workplace: A review of data and policy responses in the EU," which found that burnout had become a serious problem in Europe and that measures were needed to assess its levels among different occupations. In May 2019, the $\mathrm{WHO}^{7}$ recognized burnout as an occupational phenomenon to be included in the next version of the International Classification of Diseases. Also in 2019, the European Agency for Safety and Health at Work (EU-OSHA, 2019a,b) referred again to "The value of occupational safety and health and the societal costs of work-related injuries and diseases." Again in 2019, the results of the "Third European Survey of Enterprises on New and Emerging Risks (ESENER-3") reinforced the negative impact of job stress and the importance of occupation health in preventing occupational stress among other psychosocial risks, a topic that the $\mathrm{WHO}^{8}$ also highlighted.

According to Lazaus and Folkman (1984, p. 21), "psychological stress, therefore, is a relationship between the person and the environment that is appraised by the person as taxing or exceeding his or her resources and endangering his or her well-being." Based on this definition, the concept of stress at the workplace, job stress, or occupational stress can be defined as a "pattern of physiological, emotional, cognitive, and behavioral responses that occur when workers are presented with work demands not matched to their knowledge, skills, or abilities and which challenge their ability to cope" (Patel et al., 2017, p. 1), negatively influencing the worker's wellbeing, performance, and productivity (Quick and Henderson, 2016). Moreover, stress, especially job stress and occupational stress, are related and can predict burnout, since job stress can result from the relationship between job demands and job resources, or from the effort-reward imbalance (Peiró et al., 2001; Lin et al., 2013; Chirico, 2016; Patel et al., 2017; Salvagioni et al., 2017; Wang et al., 2017). Furthermore, burnout can be a long-term process of resource depletion and inadequate responses to chronic job stress

\footnotetext{
${ }^{6}$ https://www.who.int/mental_health/world-mental-health-day/en/.

${ }^{7}$ https://www.who.int/mental_health/evidence/burn-out/en/.

${ }^{8}$ https://www.who.int/occupational_health/topics/stressatwp/en/.
}

(Maslach et al., 2001; Schaufeli, 2017). Burnout is difficult to distinguish from depression since they share similar symptoms (Bianchi et al., 2015; Golonka et al., 2019; Koutsimani et al., 2019; Bianchi, 2020).

Using instruments that allow burnout and stress to be measured is therefore a vital necessity before designing intervention programs for resilience, stress management, and burnout or suicide prevention. However, for police officers as a professional group, those instruments must be chosen carefully, considering the specificity of their policing tasks. To identify the instruments used to measure burnout and stress among police officers, a literature search was performed between January and December 2019 on the EBSCO database of scientific papers, using the following search expression: "police officers" and "burnout or stress" and "instruments or tools or scale or questionnaire or inventory or measurement or assessment or evaluation." The search found 191 scientific published papers after removing duplicated references. However, 49 papers were focused exclusively on post-traumatic stress disorder; 26 were written in languages other than English, Portuguese, or Spanish, or the complete paper was unavailable; 5 were theoretical papers; and 3 used qualitative methods. Thus, a final number of 108 studies were analyzed, identifying the publication year, number of participants, country of the sample, and instruments used for burnout and stress or occupational stress measurement.

Results of the literature review (Table 1) revealed that most of the studies are recent (Figure 1), though the interest in questionnaires to assess burnout or job stress began in the 1970 s. In detail, 11 studies were published between 1979 and 1989, 13 between 1990 and 1999, 18 between 2000 and 2009, and 66 between 2010 and 2019. The samples came from 26 countries (Figure 2), mostly the USA (33), but Brazil appears with 12 studies, 4 or 5 studies were found in the UK, Poland, India, Canada, Spain, and the Netherlands, and 2 or 3 in Switzerland, Sweden, Portugal, Taiwan, Jamaica, Italy, Greece, Germany, and Finland. Three papers used samples from several countries in the same study. Finally, countries with only one study included Thailand, Sri Lanka, South Korea, South Africa, Pakistan, Lithuania, Israel, and China. These data express the global interest of scientific research in stress among police officers.

The sample sizes varied between 11 and 13,146 participants $(M=595 ; S D=1358.56)$. However, a more detailed analysis (Figure 3) revealed that 28 studies sampled 11-95 participants, 24 studies sampled 101-289, 20 studies sampled 305-489, 22 studies sampled 500-951, and 13 studies sampled 1000-4500 participants. One study collected data from 13,146 police officers in the USA (McCarty et al., 2019).

The analysis of measurement instruments revealed that 51 studies measured burnout (Figure 4), with the Maslach Burnout Inventory being prevalent (32 studies), while the Oldenburg Burnout Inventory was used in five studies. Three studies used other measures or developed questionnaires adapted from other instruments, while nine studies used specific but different burnout measures. Measures of job stress were found (Figure 5) in 72 studies: six used the Perceived Stress Scale, four used the Lipp Stress Inventory (from Brazil), five used the Police Stress Questionnaire, and 11 used several different police stress 
TABLE 1 | Studies using questionnaires to measure burnout or occupational stress of police officers.

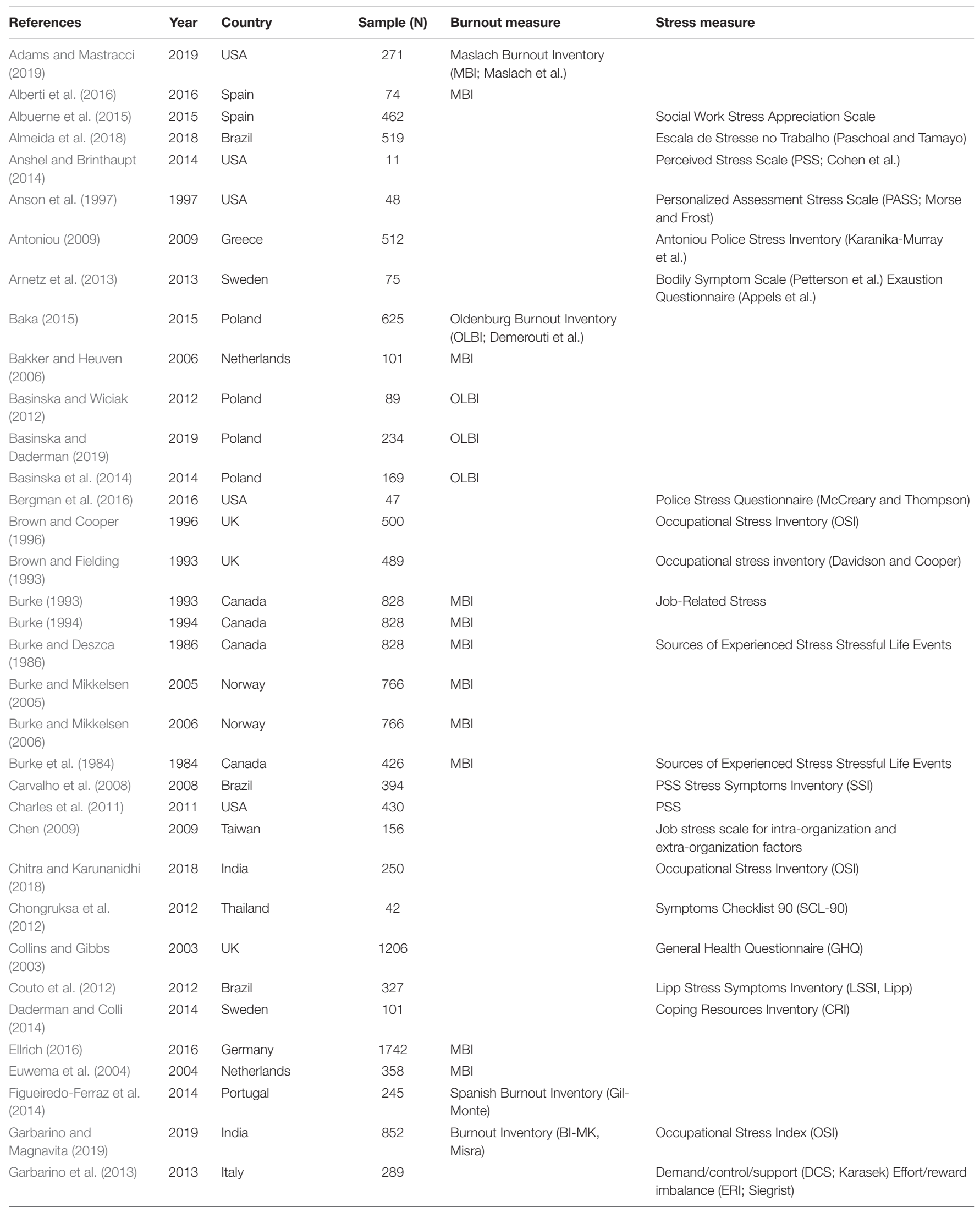


TABLE 1 | Continued

\begin{tabular}{|c|c|c|c|c|c|}
\hline References & Year & Country & Sample (N) & Burnout measure & Stress measure \\
\hline Gerber et al. (2010a) & 2010 & Switzerland & 460 & & $\begin{array}{l}\text { Trier Inventory for the Assessment of Chronic Stress } \\
\text { (TICS; Schulz et al.) }\end{array}$ \\
\hline Gerber et al. (2010b) & 2010 & Switzerland & 533 & & $\begin{array}{l}\text { Trier Inventory for the Assessment of Chronic Stress } \\
\text { (TICS; Schulz et al.) }\end{array}$ \\
\hline Gershon et al. (2009) & 2009 & USA & 1072 & & $\begin{array}{l}\text { Police Stress Scale and Police Coping Scale (Beehr } \\
\text { et al.) }\end{array}$ \\
\hline $\begin{array}{l}\text { Gomes and Afonso } \\
\text { (2016) }\end{array}$ & 2016 & Portugal & 95 & & Global Level of Stress (Kyriacou) \\
\hline Goodman (1990) & 1990 & USA & 199 & $\begin{array}{l}\text { Staff Burnout Scale for Police } \\
\text { and Security Officers (SBS-PS; } \\
\text { Jones) }\end{array}$ & Police Officer History Questionnaire (Goodman) \\
\hline Griffin and Sun (2018) & 2018 & USA & 138 & $\mathrm{MBI}$ & PSS \\
\hline Gutshall et al. (2017) & 2017 & USA & 32 & $\mathrm{MBI}$ & PSS \\
\hline Hartley et al. (2013) & 2013 & USA & 452 & & $\begin{array}{l}\text { PSS Spielberger Police Stress Survey (Spielberger } \\
\text { et al.) }\end{array}$ \\
\hline Hassell et al. (2011) & 2011 & USA & 87 & & Stress assessed by five items \\
\hline Hawkins (2001) & 2001 & USA & 452 & $\mathrm{MBI}$ & \\
\hline Houdmont (2013) & 2013 & UK & 139 & $\mathrm{MBI}$ & \\
\hline Hu et al. (2017) & 2017 & Chine & 273 & $\mathrm{MBI}$ & $\begin{array}{l}\text { Questionnaire on the Experience and Evaluation of } \\
\text { Work (Hu et al.) }\end{array}$ \\
\hline Husain et al. (2014) & 2014 & Pakistan & 315 & & $\begin{array}{l}\text { Depression Anxiety and Stress Scale (Lovibond and } \\
\text { Lovibond) }\end{array}$ \\
\hline Kaplan et al. (2017) & 2017 & USA & 72 & & $\begin{array}{l}\text { PSS Police Stress Questionnaire (McCreary and } \\
\text { Thompson) }\end{array}$ \\
\hline Kirkcaldy (1993) & 1993 & $\begin{array}{l}\text { USA, Spain, } \\
\text { Germany, UK, } \\
\text { Ireland, Holland, } \\
\text { Finland, Denmark }\end{array}$ & 42 & & Occupational Stress Indicator (Cooper et al.) \\
\hline $\begin{array}{l}\text { Kirkcaldy and Cooper } \\
\text { (1992) }\end{array}$ & 1992 & $\begin{array}{l}\text { Germany North } \\
\text { Ireland }\end{array}$ & 156 & & Occupational Stress Indicator (Cooper et al.) \\
\hline Kirkcaldy et al. (1994) & 1994 & $\begin{array}{l}\text { Germany North } \\
\text { Ireland }\end{array}$ & 156 & & Occupational Stress Indicator (Cooper et al.) \\
\hline Kirkcaldy et al. (1995) & 1995 & UK & 533 & & Occupational Stress Indicator (Cooper et al.) \\
\hline $\begin{array}{l}\text { Kop and Euwema } \\
\text { (2001) }\end{array}$ & 2001 & Netherlands & 358 & $\mathrm{MBI}$ & \\
\hline Kop et al. (1999) & 1999 & Netherlands & 358 & $\mathrm{MBI}$ & \\
\hline Korre et al. (2014) & 2014 & USA & 951 & & Daily perceived stress level \\
\hline Kuo (2014) & 2014 & Taiwan & 1315 & & Identification of job stressors \\
\hline Kwak et al. (2018) & 2018 & South Korea & 466 & $\mathrm{MBI}$ & \\
\hline Lambert et al. (2017) & 2017 & India & 827 & $\begin{array}{l}\text { Burnout questions (adapted } \\
\text { from Wright and Saylor) }\end{array}$ & Job stress (Crank et al) \\
\hline Lambert et al. (2019) & 2019 & India & 1000 & $\begin{array}{l}\text { Wright and Salyor burnout } \\
\text { measures }\end{array}$ & \\
\hline Lester (1982a) & 1982 & USA & 73 & & Subjective level of stress from job conditions \\
\hline Lester (1982b) & 1982 & USA & 41 & & Self-evaluation of stress questionnaire (Willcher) \\
\hline Lester and Mink (1979) & 1979 & USA & 15 & & Identification of job stressors \\
\hline Lester and Solis (1980) & 1980 & USA & 20 & & Self-evaluation of stress questionnaire (Willcher) \\
\hline Lester et al. (1984) & 1984 & USA & 55 & & Stress Profile (Girdano and Everly) \\
\hline Lester et al. (1985) & 1985 & USA & 48 & & Eight stress tests (Girdano and Everly) \\
\hline $\begin{array}{l}\text { Levitov and Thompson } \\
\text { (1981) }\end{array}$ & 1981 & USA & 250 & & Self Report Form (Cattell) \\
\hline Lima et al. (2018) & 2018 & Brazil & 80 & $\begin{array}{l}\text { Burnout Questionnaire (based } \\
\text { on MBI; Jbeili) }\end{array}$ & \\
\hline Lipp (2009) & 2019 & Brazil & 418 & & $\begin{array}{l}\text { Lipp Stress Symptoms Inventory (LSSI, Lipp) Police } \\
\text { Officers Stressors Questionnaire (POSQ) }\end{array}$ \\
\hline
\end{tabular}


TABLE 1 | Continued

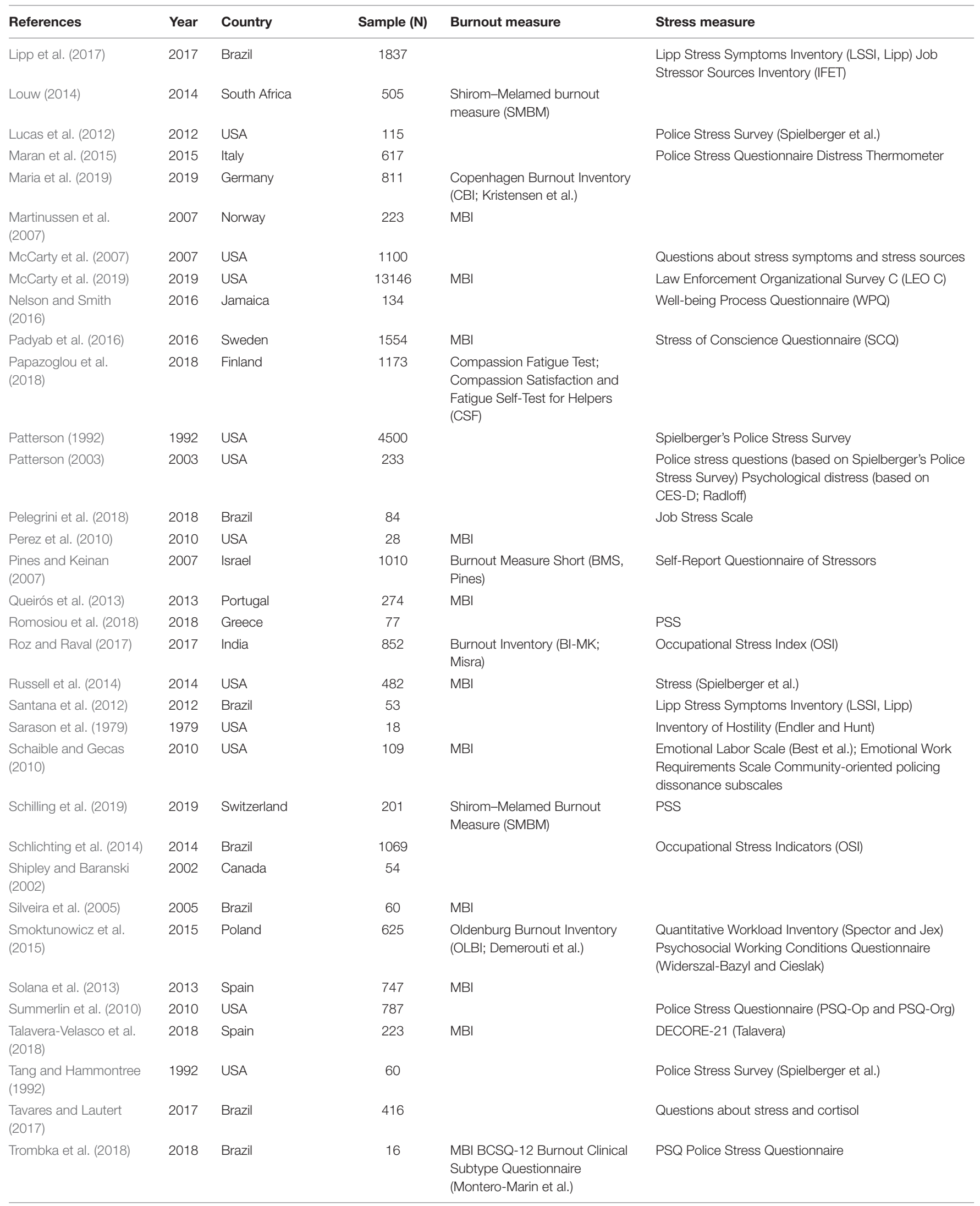


TABLE 1 | Continued

\begin{tabular}{|c|c|c|c|c|c|}
\hline References & Year & Country & Sample (N) & Burnout measure & Stress measure \\
\hline $\begin{array}{l}\text { Vuorensyrja and Malkia } \\
\text { (2011) }\end{array}$ & 2011 & Finland & 2821 & $\begin{array}{l}\text { Bergen Burnout Indicator } \\
\text { (BBl-15) }\end{array}$ & Police Personnel Barometer (PPB) \\
\hline White et al. (1985) & 1985 & USA & 355 & $\mathrm{MBI}$ & Police Stress Inventory (Spielberger et al.) \\
\hline $\begin{array}{l}\text { Wickramasinghe and } \\
\text { Wijesinghe (2018) }\end{array}$ & 2018 & Sri Lanka & 750 & $\begin{array}{l}\text { Burnout Clinical Subtype } \\
\text { Questionnaire (BCSQ-36) }\end{array}$ & \\
\hline Wray and Jarrett (2019) & 2019 & Jamaica & 305 & $\mathrm{MBI}$ & \\
\hline Zukauskas et al. (2009) & 2009 & Lithuania & 314 & & Specific questions for job stress in Lithuania \\
\hline
\end{tabular}

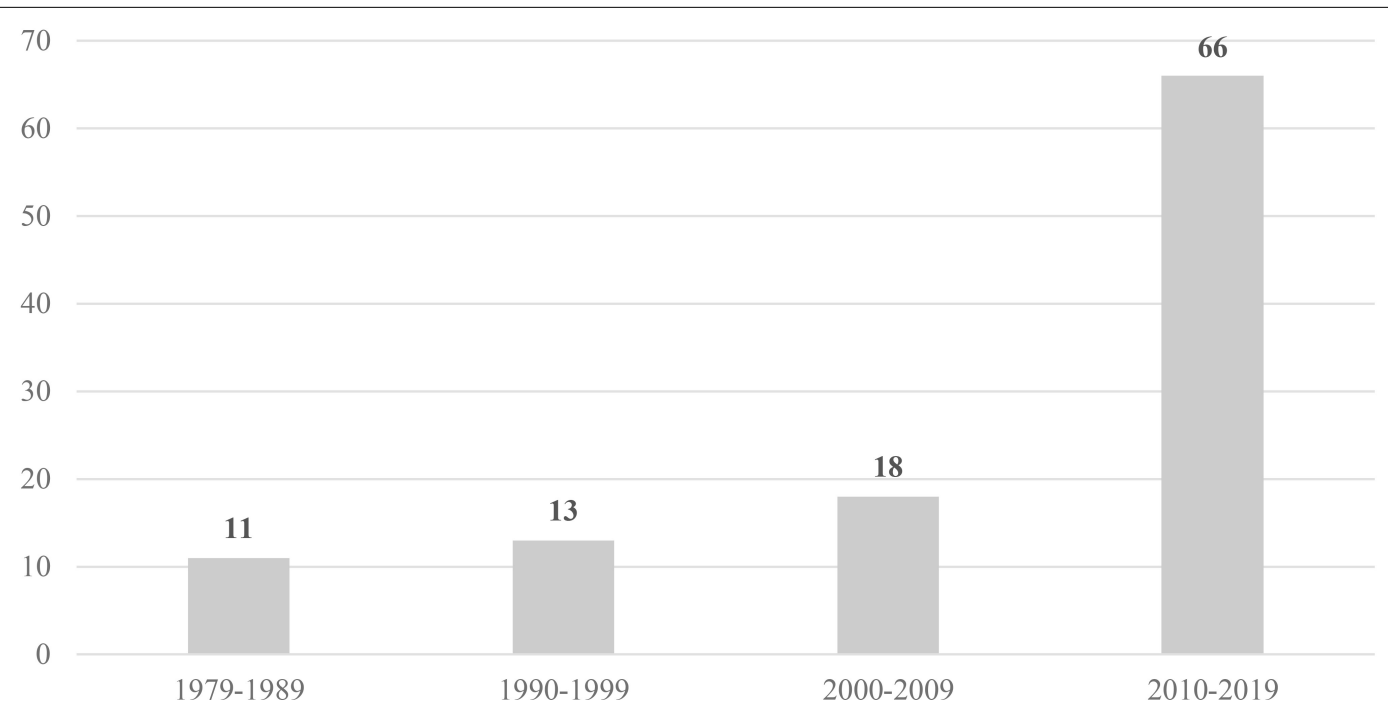

FIGURE 1 | Distribution of papers according year of publication.

questionnaires. However, 10 studies used several occupational stress inventories, 15 used several job stress questionnaires, 15 used several stress questionnaires, and six used other instruments assessing health symptoms other than stress. This review revealed the proliferation of stress measures, although some studies already used specific police stress questionnaires. It can be concluded that measuring burnout and stress among police officers is a concern for the scientific community.

In Portugal, for burnout measurement among police officers, a study used the Spanish Burnout Inventory (Gil-Monte, 2011) and demonstrated that this questionnaire had adequate psychometric properties for a sample of Portuguese police officers (FigueiredoFerraz et al., 2014). Another study (Queirós et al., 2013) used the Maslach Burnout Inventory, analyzing only Cronbach's alphas but not validating a Portuguese version. Regarding stress measurement, one study used a global measure of stress (Gomes and Afonso, 2016), but no studies were found with specific stress measures for policing. Following the analysis of the specific stress instruments found in the literature review, we decided to translate and validate a Portuguese version of the Police Stress Questionnaire for operational stress. The Police Stress Questionnaire (McCreary and Thompson, 2006) is a short measure (20 items) allowing for the assessment of operational or organizational police stress, it is freely available for research purposes and has established stress levels with cut-off points. Since some studies used global measures of stress or stress symptoms, it was decided to also use the short questionnaire Kessler Psychological Distress Scale (K10), which has a recent Portuguese version (Pereira et al., 2019). Thus, this study can contribute to the development of a Portuguese version of a specific police stress instrument, and to identify stress and burnout levels of a sample of police officers using validated instruments.

\section{MATERIALS AND METHODS}

\section{Participants}

The sample was composed of 2057 police officers of the Portuguese National Police (Polícia de Segurança Pública, PSP), a police force that works only in the cities of all 18 Portuguese districts and the Azores and Madeira Islands. The sample constitutes nearly $10 \%$ of this force and all districts were represented: Lisbon contributed $45 \%$ of the sample, Porto $19 \%$, Setubal 6\%, Faro and Azores 4\%, Madeira 3\%, and other districts between 0.3 and $2.5 \%$.

Regarding police officers' positions, $78.8 \%$ were in the "agent" category (the lowest-ranking officer), 14.6\% were "chief," and $6.5 \%$ commander (the highest rank). The most frequent tasks were patrolling (52\%), criminal investigation (17\%), and 


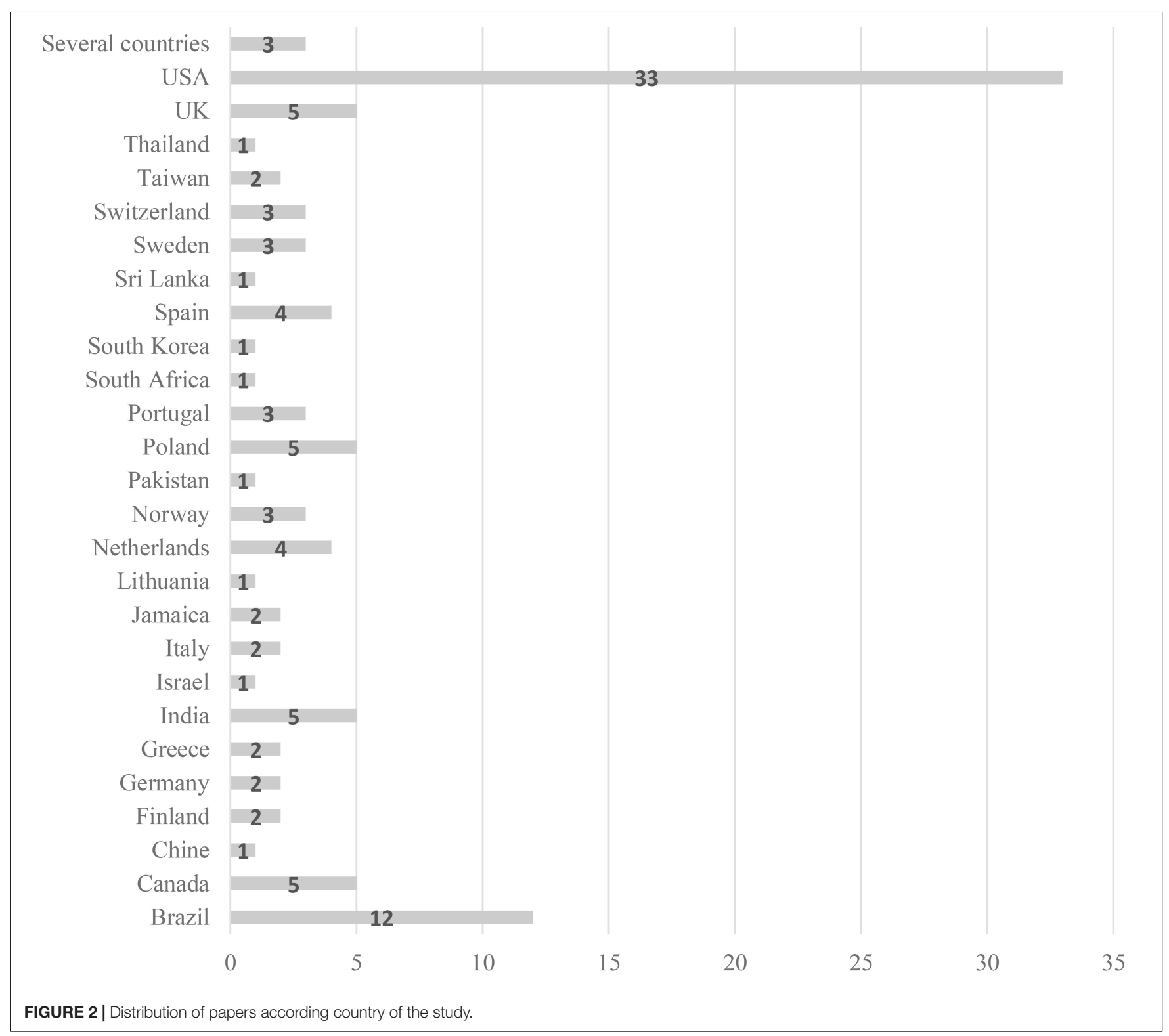

road traffic management (13\%). Other participants worked in integrated special police units, rapid intervention teams, specific proximity teams (e.g., schools or elderly safety programs), administrative services, and commander teams.

The age of the participants varied between 21 and 65 years old $(M=42.47$; $S D=8.785)$, with $33.4 \%$ between 21 and 38 years, $32.5 \%$ between 39 and 45, and the rest between 46 and 65 . Job experience in the Portuguese National Police varied between 1 and 41 years $(M=19.267 ; S D=9.036)$, with $32.3 \%$ of the sample between 1 and 14 years, 34.7\% between 15 and 23 years, and the rest between 24 and 41 years. Regarding gender, 92\% were men and $8 \%$ women, while overall women represent nearly $10 \%$ of the police force. To avoid the possible identification of individuals from the matching of position, age, gender, and district, no statistical analyses were performed that combined these data, and no other sociodemographic data were collected.

\section{Measures}

The questionnaire was composed of four major groups of questions, the first characterizing the sociodemographic data (age, sex, job experience, district, position, and job task). The second group was composed of the Operational Police Stress Questionnaire (PSQ-Op), developed by McCreary and Thompson $(2004,2006)$ to assess the specificities of job stress among police officers both for operational and organizational stress sources (PSQ-Op and PSQ-Org). This study used the operational stress sources only. The PSQ-Op questionnaire is composed of 20 items evaluated on a 7-point scale ranging from 1 ("not at all stressful" or "no stress at all") to 7 ("very stressful" or "a lot of stress"), with 4 indicating moderate stress. The authors were contacted by email to obtain permission for the Portuguese version, but no answer was obtained for the PSQ-Op as it is provided free for non-commercial, educational, 

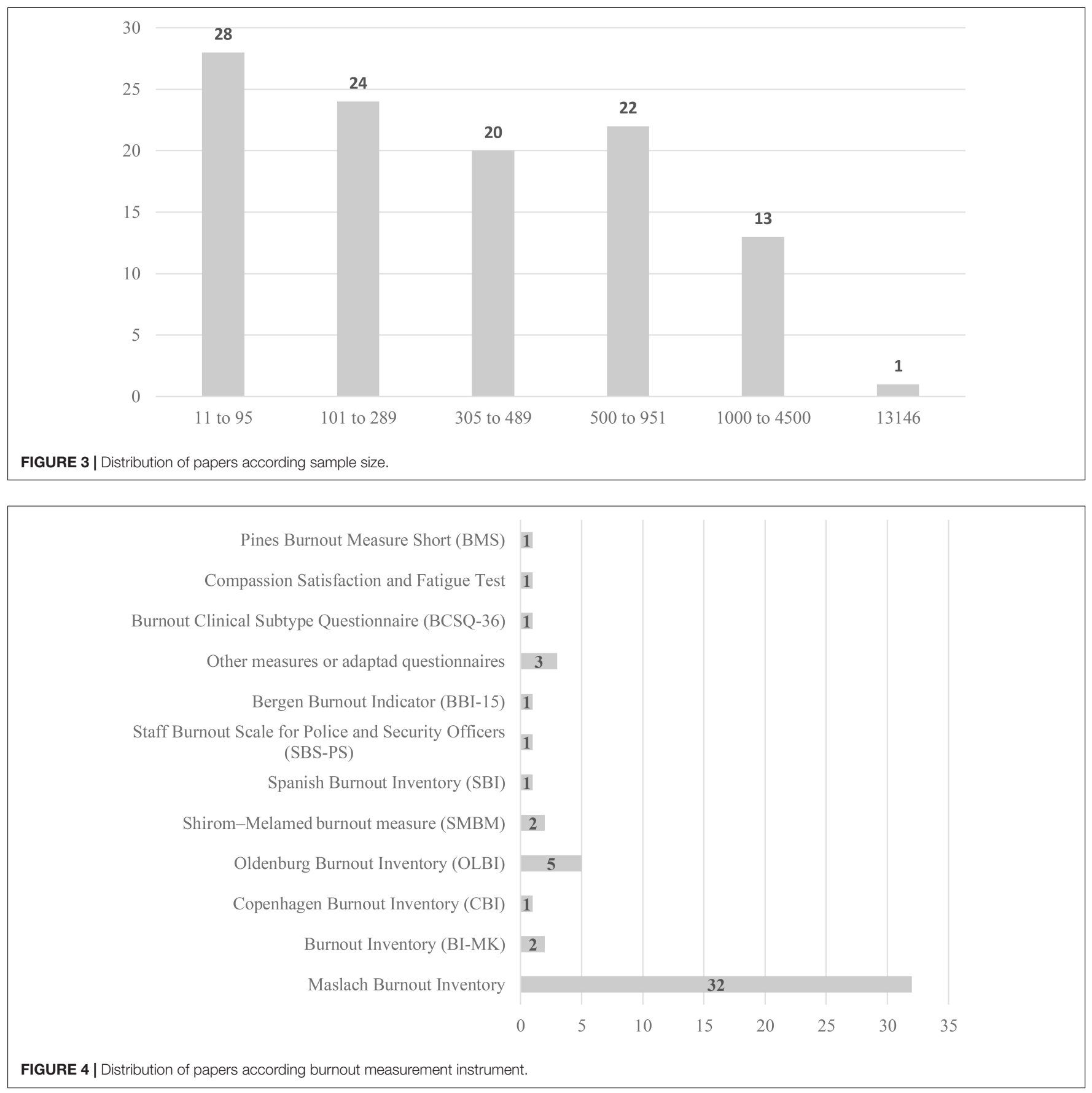

and research purposes ${ }^{9}$. In later developments, McCreary et al. (2017) established norms and cut-off values, with values below 2.0 indicating low stress, between 2.1 and 3.4 moderate stress, and above 3.5 high stress. As far as we know, no Portuguese version of the PSQ-Op has been published, and two psychologists (one conducting research about policing and police forces, another working with police officers) translated the questionnaire into Portuguese. Another researcher, unfamiliar with police officers' work, subsequently back-translated the questionnaire

\footnotetext{
${ }^{9}$ https://www.midss.org/sites/default/files/psq-op.pdf.
}

into English and compared it with the original version. Finally, these three researchers discussed each item with two police officers (a patrol police officer and a police station commander) until a lexical and cultural consensus was obtained, including suggestions from the police officers to add some examples adapted for Portuguese situations (Table 2). A pilot study was performed with 20 police officers to ensure that the questionnaire was easy to complete and was applicable to the Portuguese situation, and no major changes were made.

The third group of questions was composed from the Spanish Burnout Inventory (SBI, Gil-Monte, 2011), using a 


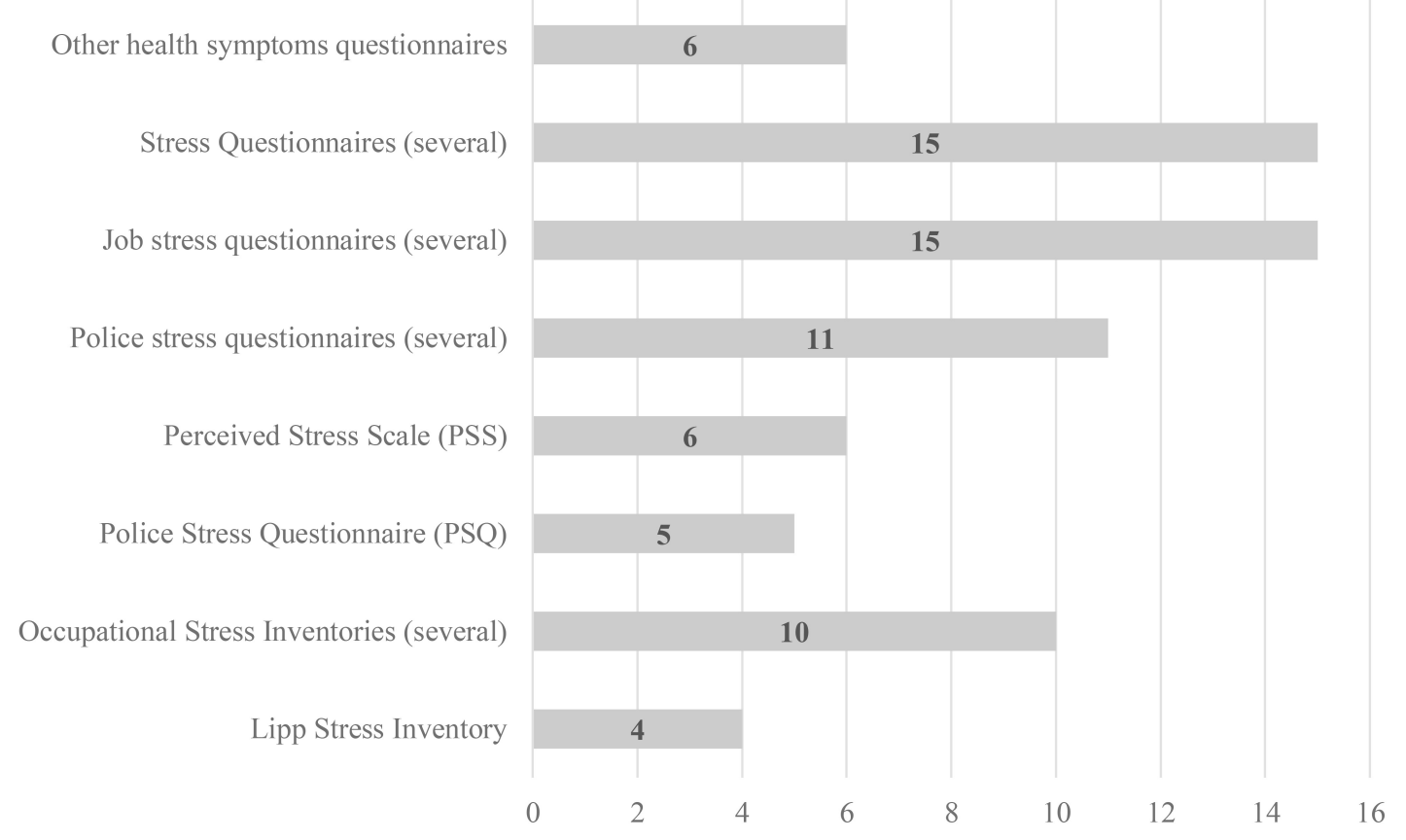

FIGURE 5 | Distribution of papers according stress measurement instrument.

Portuguese version already tested on police officers, having demonstrated adequate psychometric properties (FigueiredoFerraz et al., 2014). This instrument considers burnout as a process of cognitive and emotional deterioration, involving attitudes of indifference and guilt (Gil-Monte and ManzanoGarcía, 2015). It includes 20 items organized on four scales: (1) enthusiasm for the job (demonstrating, for instance, the ambition to accomplish a person's professional goals because they are a source of personal achievement); (2) psychological exhaustion (emotional and physical exhaustion related to job tasks, increased by dealing every day with people who present difficulties or problems); (3) indolence (negative attitudes of indifference and cynicism when dealing with persons demanding things related to a person's job tasks); and (4) guilt (negative feelings, behaviors, and attitudes in the workplace, elicited by interactions during labor relations). Each item is assessed by a 5-point frequency scale ranging from 0 (never) to 4 (very frequent or every day). Low scores on Enthusiasm for the Job, along with high scores on Psychological Exhaustion, Indolence, and Guilt, indicate high levels of burnout. Scores for each of the four scales are calculated using the mean of the items that compose each scale, and a global score for burnout is then calculated after reversing the items of the Enthusiasm scale. According to Poletto et al. (2016), it is possible to use percentile analysis to identify burnout at very low levels $(P \leq 10)$, low levels $(11<P \leq 33)$, moderate

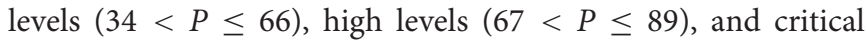
levels $(P \geq 90)$.

The fourth and last group of questions was composed from the Kessler Psychological Distress Scale (K10), from Kessler et al. (2002, 2003). We used the Portuguese version by Pereira et al. (2019), who described K10 as having 10 items that assess the frequency of non-specific psychological distress symptoms during the last month, being a self-report measure based on questions about the symptoms of anxiety and depression. All items are assessed on a 5-point scale ( $1=$ "none of the time" to $5=$ "all of the time") and the sum of the scores indicates the stress level, where high scores correspond to high stress levels. Using this sum it is possible to identify cut-off points of stress levels, where 10-15 points correspond to "low distress," 16-21 points to "moderate," 22-29 points to "high," and 30-50 points to "very high." Values between 22 and 50 points indicate a risk of developing a psychological disorder (Andrews and Slade, 2001; Pereira et al., 2019).

\section{Procedure}

After formal authorization by the Directorate of the Portuguese National Police to develop the study and collect data among the police officers, an online questionnaire was prepared on Google Forms with a link inviting participation in a study of burnout and occupational stress among police officers. The Directorate disseminated this link to the police officers using their professional email addresses. There was no direct contact between participants and researchers, and data were collected in September and October 2019. No exclusion criteria existed, and participation was voluntary. The participation rate was nearly $10 \%$ of the number of police officers that constitute this police force. Researchers were unable to identify how many police officers read the email and/or followed the link and decided not to participate. This study was carried out in accordance with the recommendations of the Ethics guidelines of the FPCEUP Ethics Committee, 
TABLE 2 | PSQ-Op original and Portuguese versions.

\begin{tabular}{|c|c|c|c|c|c|}
\hline \multicolumn{3}{|c|}{ Original PSP-Op (McCreary and Thompson (2006)) } & \multicolumn{3}{|c|}{ Portuguese version of PSQ-Op } \\
\hline No stress at all & Moderate stress & A lot of stress & Nenhum stress & Stress moderado & Muito stress \\
\hline 1 & 4 & 7 & 1 & 4 & 7 \\
\hline \multicolumn{3}{|l|}{ 1. Shift work } & \multicolumn{3}{|c|}{ 1. Trabalhar por turnos } \\
\hline \multicolumn{3}{|c|}{ 2. Working alone at night } & \multicolumn{3}{|c|}{ 2. Trabalhar sozinho à noite } \\
\hline \multicolumn{3}{|c|}{ 3. Over-time demands } & \multicolumn{3}{|c|}{ 3. Exigências relacionadas com horas extra ou serviço imprevisto } \\
\hline \multicolumn{3}{|c|}{ 4. Risk of being injured on the job } & \multicolumn{3}{|c|}{ 4. Risco ou possibilidade de ser ferido durante o trabalho } \\
\hline \multicolumn{3}{|c|}{ 5. Work related activities on days off (e.g., court, community events) } & \multicolumn{3}{|c|}{$\begin{array}{l}\text { 5. Ter atividades relacionadas com o trabalho em dias de folga (ex.: } \\
\text { comparecer em tribunal, eventos na comunidade) }\end{array}$} \\
\hline \multicolumn{3}{|c|}{ 6. Traumatic events (e.g., MVA, domestics, death, injury) } & \multicolumn{3}{|c|}{$\begin{array}{l}\text { 6. Acontecimentos traumáticos (ex.: acidentes rodoviários, violência } \\
\text { doméstica, mortes, agressões) }\end{array}$} \\
\hline \multicolumn{3}{|c|}{ 7. Managing your social life outside of work } & \multicolumn{3}{|c|}{ 7. Gerir a sua vida social fora do trabalho } \\
\hline \multicolumn{3}{|c|}{ 8. Not enough time available to spend with friends and family } & \multicolumn{3}{|c|}{ 8. Ter pouco tempo disponível para passar com os amigos ou família } \\
\hline \multicolumn{3}{|c|}{ 9. Paperwork } & \multicolumn{3}{|c|}{ 9. Aspetos burocráticos do serviço (ex.: relatórios) } \\
\hline \multicolumn{3}{|c|}{ 10. Eating healthy at work } & \multicolumn{3}{|c|}{ 10. Conseguir comer de forma saudável no trabalho } \\
\hline \multicolumn{3}{|c|}{ 11. Finding time to stay in good physical condition } & \multicolumn{3}{|c|}{ 11. Conseguir arranjar tempo para ficar em boa forma física } \\
\hline \multicolumn{3}{|c|}{ 12. Fatigue (e.g., shift work, over-time) } & \multicolumn{3}{|c|}{ 12. Andar cansado (ex.: por trabalhar por turnos, horas extraordinárias) } \\
\hline \multicolumn{3}{|c|}{ 13. Occupation-related health issues (e.g., back pain) } & \multicolumn{3}{|c|}{$\begin{array}{l}\text { 13. Ter problemas de saúde relacionados com a profissão (ex.: dores de costas } \\
\text { ou dores nas pernas por patrulhar a pé) }\end{array}$} \\
\hline \multicolumn{3}{|c|}{ 14. Lack of understanding from family and friends about your work } & \multicolumn{3}{|c|}{$\begin{array}{l}\text { 14. Falta de compreensão da família e amigos em relação às exigências do seu } \\
\text { trabalho }\end{array}$} \\
\hline \multicolumn{3}{|c|}{ 15. Making friends outside the job } & \multicolumn{3}{|c|}{ 15. Conseguir fazer amigos fora do trabalho } \\
\hline \multicolumn{3}{|c|}{ 16. Upholding a "higher image" in public } & \multicolumn{3}{|c|}{ 16. Conseguir manter uma boa imagem na sociedade } \\
\hline 17. Negative com & from the public & & 17. Escutar come & negativos por parte & cidadãos \\
\hline 18. Limitations to & ocial life (e.g., who yc & ends are, where you socialize) & $\begin{array}{l}\text { 18. Ter limitações } \\
\text { onde convive) }\end{array}$ & vida social (ex.: quer & os seus amigos, locais \\
\hline 19. Feeling like yo & lways on the job & & 19. Sentir-se com & stivesse sempre a trak & \\
\hline 20. Friends/family & e effects of the stigm & sociated with your job & $\begin{array}{l}\text { 20. Os amigos e f } \\
\text { profissão }\end{array}$ & entirem os efeitos do & tigma associado à sua \\
\hline $\begin{array}{l}\text { The Operational } \\
\text { non-commercial, } \\
\text { - McCreary, D.R., } \\
\text { Questionnaire (PS } \\
\text { Science. Retrieve }\end{array}$ & $\begin{array}{l}\text { tress Questionnaire } \\
\text { ional, and research p } \\
\text { hompson, M.M. (201 } \\
\text { Measurement Instru } \\
\text { www.midss.ie }\end{array}$ & $\begin{array}{l}\text { vided free for } \\
\text { ses. Cite as: } \\
\text { ne Operational Police Stress } \\
\text { Database for the Social }\end{array}$ & $\begin{array}{l}\text { O Questionário de } \\
\text { comercial, educac } \\
\text { - versão original d } \\
\text { Operational Police } \\
\text { Database for the }\end{array}$ & $\begin{array}{l}\text { s Operacional é de ac } \\
\text { investigação. Citar c } \\
\text { Yreary, D. R., and Tho } \\
\text { s Questionnaire (PSQ } \\
\text { Science. Retrieved fro }\end{array}$ & $\begin{array}{l}\text { o livre para efeitos de uso não } \\
\text { son, M. M. (2013). The } \\
\text {. Measurement Instrument } \\
\text { www.midss.ie }\end{array}$ \\
\hline & & & $\begin{array}{l}\text { - Queirós, C., Pas } \\
\text { A. (2020). Burnou } \\
\text { and a study with } t \\
\text { 11, 587. doi: } 10.3\end{array}$ & $\begin{array}{l}\text { Bártolo, A., Marques } \\
\text { tress measurement ir } \\
\text { arational police stress } \\
\text { syg.2020.00587. }\end{array}$ & $\begin{array}{l}\text { J., Silva, C. F., and Pereira, } \\
\text { ce officers: literature review } \\
\text { tionnaire. Front. Psychol. }\end{array}$ \\
\hline
\end{tabular}

having online informed consent from all participants in accordance with the Declaration of Helsinki. Thus, before responding to the questionnaire, participants were asked to provide their informed consent, with the notification that data would be gathered anonymously. Data were accessed by one researcher only, who downloaded the Excel file and converted it to SPSS format.

\section{Data Analysis}

Statistical analysis was performed using Statistical Package for Social Sciences, version 24 (SPSS Inc., Chicago) and Analysis of Moment Structures (AMOS) version 24. In the first stage, preliminary analyses were conducted in order to assess descriptive statistics, and normality and non-multicollinearity at item level. To test the factorial structure of the PSQ-Op, we used a combination of Exploratory Factor Analysis (EFA) and Confirmatory Factor Analysis (CFA). The sample was randomly split into two samples through the randomization function in SPSS. With the first part of the sample $(n=636)$, an EFA using Principal Axis Factoring (PAF) with direct oblimin rotation was conducted to identify a viable factor structure by extracting the minimum number of factors that explained the maximum variance in the 20-item scale. With the remaining sample, a CFA was performed to verify if the solution obtained from the EFA presented an acceptable fit. The root mean square error of approximation (RMSEA), the comparative fit index (CFI), and the standardized root mean square residual (SRMR) were the three indicators used to evaluate the model's fit. An acceptable-fit model was determined if RMSEA $\leq 0.08$, CFI $>0.90$, and SRMR $<0.10$ (Kline, 2005). The chi-square test $\left(\chi^{2}\right)$ was reported for completeness, but not used to check the model fit due to its sensibility to large samples (Kelloway, 1995). Based on the multivariate normality violations, CFA used the maximum likelihood estimation with 
bootstrapping (1000 resamples). The Bollen-Stine bootstrap $p$ was an index fit also reported. Alternative factor models were generated and tested according to the modification indexes $(\mathrm{MI}>11)$.

Convergent validity was assessed by computing the average variance extracted with values of AVE $\geq 0.50$ indicating satisfactory validity. In turn, in order to investigate the evidence of discriminant validity, we examined whether the AVE values were equal to or greater than the squared correlation between the factors ( $r^{2}$ DV $)$ (Maroco, 2014). Following the model specification, reliability was investigated using (a) Cronbach's alpha coefficient and (b) composite reliability for each factor and for the overall scale.

Finally, the relationship between the PSQ-Op dimensions and distress and burnout symptoms was determined from the Pearson correlation coefficients including the entire sample, as well as the descriptive statistics, which allowed us to identify burnout, distress, and operational stress levels.

\section{RESULTS}

Since there are no specific measures for operational stress among police officers, it was necessary to evaluate the psychometric properties of the Portuguese version of the PSQ-Op before identifying burnout, distress, and operational stress levels.

\section{Preliminary Analysis: Item Properties}

As shown in Table 3, all possible Likert-scale answer values for each item were observed. The mean for most items was close to 5. The overall mean response for the 20 items was $4.97(S D=0.45)$ No deviations from the normal distribution were found considering skewness $(S k,<3.0)$ and kurtosis $(K u, \leq 7.0)$ absolute values (Byrne, 2016). All items presented significant positive corrected item-total correlations $(\geq 0.40)$ and low variation in reliability if the item was deleted. Inter-correlations among all items were significant and no multicollinearity was obtained $(0.390 \leq r \leq 0.731)$ (Tabachnick and Fidell, 2001). Based on this analysis, 20 items were retained for subsequent analyses.

\section{Exploratory Factor Analysis (EFA)}

In order to examine the factor structure, an EFA was conducted based on a randomized split of the data in the sample $(n=636)$. EFA using principal axis factor analysis with promax rotation determined the factor structure of the 20 items of the questionnaire. The Kaiser-Meyer-Olkin (KMO) measure presented a value of 0.964 and Bartlett's test of sphericity was significant $\left(\chi^{2}=9621.92, p<0.001\right)$, validating the correlation matrix structure. EFA yielded a 20-item measure with a two-factor solution (Table 4): nine items included content related to social issues (items 7, 8, and 14-20), which expressed the feeling that a police officer is always on the job, as well as facing difficulties in managing personal life or balancing work and family, and having to deal with the public/social image of the police force and citizens' negative comments; the other eleven items included content that reflected work issues (items related to specific details of policing tasks such as shift work, paperwork, injuries, fatigue, and traumatic events). These two factors together (social issues and work issues) accounted for $60.30 \%$ of the total variance. A good internal consistency for each factor was estimated using Cronbach's alpha coefficients: factor $1, \alpha=0.937$ and factor $2, \alpha=0.933$.

\section{Confirmatory Factor Analysis (CFA) Two-Factor Model}

Mardia's coefficient for the PSQ-Op was 181.19, indicating violation of the multivariate normality, so a maximum likelihood estimation with bootstrapping was used to generate accurate estimations of standard errors (bias-corrected at the 95\% confidence level). The two-factor model derived from EFA was then cross-validated on 1421 participants retained from the entire sample. This solution was run and demonstrated a marginal fit, since the CFI value was above 0.87 and RMSEA and SRMR values were below 0.10 (Bong et al., 2013). The factor loadings of items were above 0.65 (Table 5). The BollenStine value $(p=0.001)$ suggested a poor fit $(p>0.05$ according to Bollen and Stine, 1992), but this result might have been affected by the large sample size. High correlations between factors were observed.

\section{Convergent and Discriminant Validity Evidence}

Values of AVE indicated the construct's convergent evidence. AVE was determined for social issues (AVE = 0.59) and work issues (AVE $=0.54)$. Concerning the discriminant validity, AVE of the factors was compared to the $r^{2} \mathrm{DV}$. AVE for the two scales was smaller than $r^{2} \mathrm{DV}=0.76$. These data confirmed that the factors are strongly related to each other, indicating that a unidimensional model or a second-order latent model may be admissible solutions.

\section{Unidimensional and Second-Order Models}

A single latent model where the factor of operational police stress loads on all 20 items presented a poor fit. Higher error covariance was observed in more than $50 \%$ of the items. Based on this result, no additional covariance paths were allowed between error terms. Thus, we examined fit indices for a second-order solution called operational police stress (Table 5), integrating the social and work issues. Based on the high modification indices, allowing errors to covary for items 3 and 5, 4 and 6, 10 and 11, and 15 and 16 improved the model fit. The PSQOp second-order construct (Figure 6) presented an acceptable fit based on the values of CFI, RMSEA, and SRMR fit indices. All factor loadings were statistically significant $(p<001)$. The constrained structural weights from operational police stress to social and work factors were high $(\hat{Y}=0.89, \hat{Y}=0.98$, $p<0.001$, respectively).

\section{Internal Consistency Evidence}

To examine the reliability of the scores in the final model, we used Cronbach's alpha coefficient and composite 
TABLE 3 | Descriptive statistics about PSQ-Op items $(n=2057)$.

\begin{tabular}{|c|c|c|c|c|c|c|c|c|}
\hline Item & $\mathbf{M}$ & Min & Max & SD & Skewness & Kurtosis & Corrected item-total correlation & Cronbach's alpha if item deleted \\
\hline 1 & 5.19 & 1 & 7 & 1.764 & -0.747 & -0.330 & 0.664 & 0.955 \\
\hline 2 & 5.36 & 1 & 7 & 1.863 & -0.942 & -0.231 & 0.631 & 0.956 \\
\hline 3 & 5.46 & 1 & 7 & 1.648 & -0.932 & -0.031 & 0.630 & 0.955 \\
\hline 4 & 5.08 & 1 & 7 & 1.809 & -0.613 & -0.673 & 0.562 & 0.955 \\
\hline 5 & 5.53 & 1 & 7 & 1.681 & -1.052 & 0.210 & 0.596 & 0.955 \\
\hline 6 & 5.14 & 1 & 7 & 1.750 & -0.739 & -0.467 & 0.544 & 0.955 \\
\hline 7 & 4.34 & 1 & 7 & 1.884 & -0.199 & -1.038 & 0.557 & 0.955 \\
\hline 8 & 5.27 & 1 & 7 & 1.676 & -0.763 & -0.331 & 0.586 & 0.954 \\
\hline 9 & 4.92 & 1 & 7 & 1.707 & -0.548 & -0.607 & 0.451 & 0.955 \\
\hline 10 & 5.15 & 1 & 7 & 1.752 & -0.749 & -0.396 & 0.633 & 0.955 \\
\hline 11 & 4.94 & 1 & 7 & 1.730 & -0.567 & -0.586 & 0.616 & 0.955 \\
\hline 12 & 5.57 & 1 & 7 & 1.574 & -1.025 & 0.260 & 0.681 & 0.954 \\
\hline 13 & 5.21 & 1 & 7 & 1.740 & -0.782 & -0.363 & 0.571 & 0.954 \\
\hline 14 & 4.56 & 1 & 7 & 1.861 & -0.362 & -0.928 & 0.561 & 0.955 \\
\hline 15 & 4.02 & 1 & 7 & 1.995 & -0.037 & -1.207 & 0.650 & 0.955 \\
\hline 16 & 4.13 & 1 & 7 & 1.992 & -0.123 & -1.175 & 0.630 & 0.955 \\
\hline 17 & 5.21 & 1 & 7 & 1.758 & -0.736 & -0.551 & 0.545 & 0.955 \\
\hline 18 & 4.50 & 1 & 7 & 1.915 & -0.293 & -1.063 & 0.722 & 0.954 \\
\hline 19 & 5.03 & 1 & 7 & 1.792 & -0.637 & -0.647 & 0.670 & 0.954 \\
\hline 20 & 4.76 & 1 & 7 & 1.837 & -0.459 & -0.847 & 0.660 & 0.954 \\
\hline
\end{tabular}

TABLE 4 | Factors extracted from the exploratory factor analysis (EFA): communalities and factor loadings $(n=636)$.

\begin{tabular}{|c|c|c|c|c|c|}
\hline \multirow[b]{2}{*}{ Item } & \multirow[b]{2}{*}{ Communality } & \multicolumn{2}{|c|}{ Pattern Matrix } & \multicolumn{2}{|c|}{ Structure Matrix } \\
\hline & & $\mathbf{F 1}$ & F2 & F1 & $\mathbf{F} 2$ \\
\hline 1 & 0.583 & & 0.810 & 0.540 & 0.763 \\
\hline 2 & 0.551 & & 0.833 & 0.492 & 0.737 \\
\hline 3 & 0.706 & & 0.902 & 0.586 & 0.838 \\
\hline 4 & 0.521 & & 0.713 & 0.543 & 0.722 \\
\hline 5 & 0.582 & & 0.713 & 0.597 & 0.762 \\
\hline 6 & 0.512 & & 0.671 & 0.558 & 0.715 \\
\hline 7 & 0.567 & 0.660 & & 0.749 & 0.611 \\
\hline 8 & 0.517 & 0.406 & & 0.677 & 0.666 \\
\hline 9 & 0.479 & & 0.452 & 0.623 & 0.665 \\
\hline 10 & 0.575 & & 0.481 & 0.687 & 0.726 \\
\hline 11 & 0.547 & & 0.420 & 0.684 & 0.696 \\
\hline 12 & 0.680 & & 0.701 & 0.679 & 0.818 \\
\hline 13 & 0.607 & & 0.528 & 0.695 & 0.753 \\
\hline 14 & 0.605 & 0.713 & & 0.776 & 0.615 \\
\hline 15 & 0.659 & 0.948 & & 0.801 & 0.509 \\
\hline 16 & 0.633 & 0.825 & & 0.795 & 0.574 \\
\hline 17 & 0.547 & 0.606 & & 0.731 & 0.619 \\
\hline 18 & 0.784 & 0.938 & & 0.884 & 0.626 \\
\hline 19 & 0.701 & 0.723 & & 0.831 & 0.684 \\
\hline 20 & 0.705 & 0.781 & & 0.838 & 0.658 \\
\hline Explained variance & - & & & $54.48 \%$ & $5.83 \%$ \\
\hline Factor correlation & & & 745 & & \\
\hline
\end{tabular}

Bolded values highligthed the factor where the item was considered in the Structure Matrix.

reliability. Good internal consistency was obtained in the higher-order construct $(\alpha=0.96)$ and, simultaneously, for the first-order factors $(\alpha=0.93)$. Composite reliability coefficients presented values of 0.92 and 0.93 respectively for factors with content related to work and social issues. 
TABLE 5 | Confirmatory factor analysis (CFA): fit indexes for each model tested $(n=1421)$.

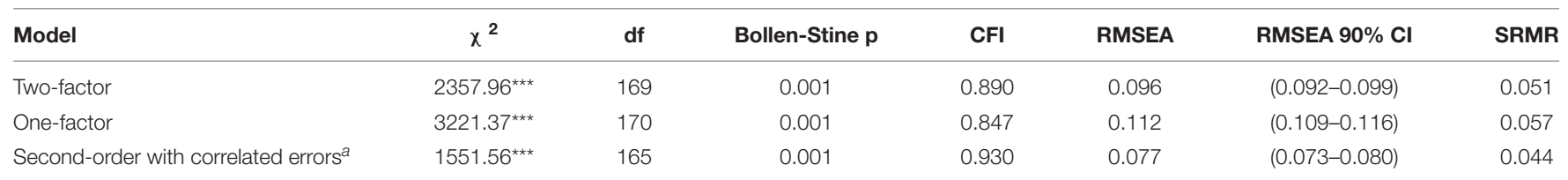

${ }^{* * *} \mathrm{p}<0.001 ;{ }^{a}$ Added path between error terms for items 3 and 5, 4 and 6, 10 and 11, 15 and 16,; $\chi^{2}$-chi-square; CFI, Comparative Fit Index; RMSEA, Root Mean Square Error of Approximation, SRMR, Standardized Root Mean Square Residual.

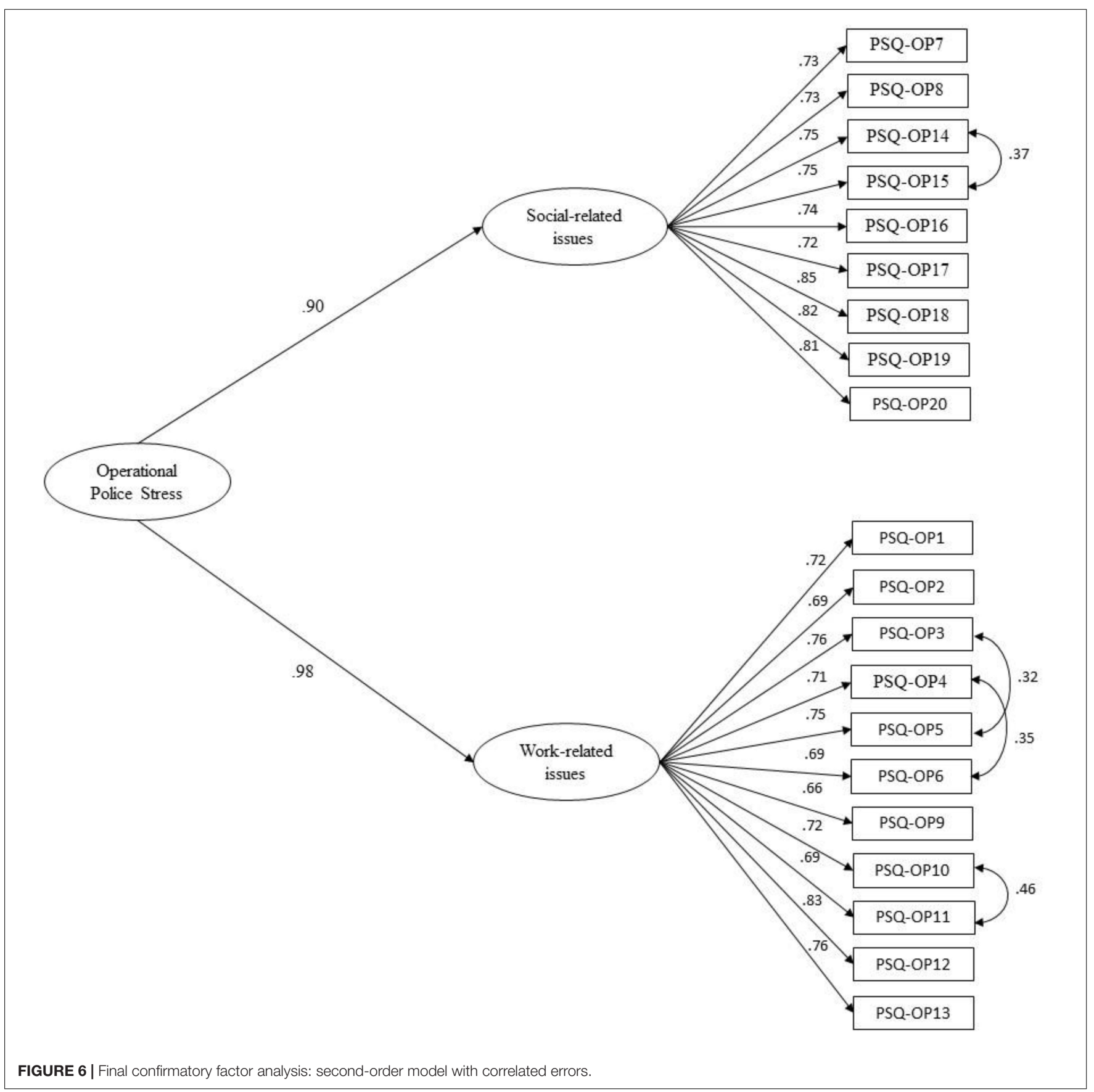




\section{Relationship of PSQ-Op Factors to Distress and Burnout}

The PSQ-Op dimensions obtained from the factorial analysis were associated with measures of distress and burnout for the overall sample (Table 6). Positive and moderate to strong correlations (Ratner, 2009) were found, demonstrating the convergent validity of this tool (except for Guilt where correlations were weaker). Higher scores on operational police stress dimensions, such as problems directly related to working conditions and to the impact of work on family and social life, were associated with increased scores in other scales of distress and burnout, except for Enthusiasm, which presented negative correlations. Considering the correlation values, it seems that social-related issues contributes most for burnout and distress compared to work-related issues.

\section{Psychological Indicators}

Analyses of all the questionnaire scales (Table 7) revealed that the sample presented at least one participant with the minimum or maximum value allowed by the scales' range. The mean values for operational stress were moderate, being higher for Social-related issues than for Operational stress global score and Work-related issues. Moderate mean values were also found for burnout, being higher for Psychologic Exhaustion and Indolence than for Enthusiasm and Burnout, while Guilt presented a low value. Finally, moderate values were found for Distress, being higher (proportionally) for Anxiety and Distress than for Depression, though very similar. These results are based on mean values of the sample inside each scale range.

However, a more detailed analysis was performed considering established levels and cut-off points for each questionnaire (Table 8). For operational stress, the sample presented high stress for $89 \%$ on Work-related issues, $84.8 \%$ for Operational stress, and $76.2 \%$ for Social-related issues, while low stress was recorded at 2.5, 2.7, and 5.9\%, respectively for each dimension, suggesting that police officers are experiencing high stress levels and, as referred, not moderates stress according to the mean values. Regarding burnout, $10.6 \%$ of the sample presented a very low level and $25.3 \%$ a low level for Enthusiasm, while $16.5 \%$ presented a high level and $10.6 \%$ a critical level for Psychological Exhaustion. For Indolence, those values were respectively 21.8 and $9.7 \%$ for Guilt, 20.3 and 8.9\%, and for Burnout 21.9 and $10.7 \%$. Finally, for Distress, $21.2 \%$ presented low stress, $26.5 \%$ high stress, and $28 \%$ very high stress, with $54.5 \%$ at risk of developing a psychological disorder. This suggests the importance of using cut-off points for each instrument, since they allow us to obtain more detailed information.

\section{DISCUSSION}

The literature review showed that the most used psychological measures are not specific nor validated for the specificities of policing tasks. A previous study (Figueiredo-Ferraz et al., 2014) demonstrated that the Spanish Burnout Inventory has adequate psychometric properties for police officers. Furthermore, the Portuguese version of the Police Stress Questionnaire for operational stress also revealed adequate psychometric properties, having a second-order construct but also the possibility to consider two scales that measure workrelated issues and social-related issues. However, Irniza et al. (2014) found a unidimensional construct on PSQ-Op for Malay police officers.

Using those two measures combined with a short measure of distress, it was possible to identify burnout, distress, and operational stress among a large national sample of Portuguese police officers, representing nearly $10 \%$ of the entire Portuguese police force. The results showed that the mean values of burnout, distress, and operational stress were moderate, but the cut-off points revealed that operational stress and its scales of workrelated issues and social-related issues presented high stress levels for more than $75 \%$ of the sample $(85,89$, and $76 \%$, respectively).

These results are in line with other studies, such as the research by Lipp et al. (2017), who found that 52\% of their sample felt stressed, and the study by Brown and Cooper (1996), who also found high stress levels. In the original study for the development of the PSQ-Op, McCreary and Thompson (2006) found that the mean values among Canadian police officers for the 20 items varied between 2.66 and 4.40 and that operational

TABLE 6 | Relationship between PSQ-OP latent variables and distress and burnout symptoms $(n=2057)$.

\begin{tabular}{|c|c|c|c|}
\hline Questionnaires' scales & Work-related issues & Social-related issues & Operational stress \\
\hline Work-related issues & 1.000 & & \\
\hline Social-related issues & $0.803^{\star *}$ & 1.000 & \\
\hline Operational stress & $0.953^{\star \star}$ & $0.946^{\star \star}$ & 1.000 \\
\hline Enthusiasm & $-0.356^{\star \star}$ & $-0.373^{\star \star}$ & $-0.383^{\star \star}$ \\
\hline Psychological exhaustion & $0.587^{\star \star}$ & $0.606^{\star \star}$ & $0.628^{\star \star}$ \\
\hline Indolence & $0.546^{\star \star}$ & $0.578^{\star \star}$ & $0.591^{\star \star}$ \\
\hline Guilt & $0.131^{\star \star}$ & $0.220^{\star \star}$ & $0.183^{\star \star}$ \\
\hline Burnout & $0.550^{\star \star}$ & $0.596^{\star \star}$ & $0.602^{\star \star}$ \\
\hline Anxiety & $0.489^{\star *}$ & $0.549^{\star \star}$ & $0.545^{\star \star}$ \\
\hline Depression & $0.497^{\star \star}$ & $0.562^{\star \star}$ & $0.556^{\star \star}$ \\
\hline Distress & $0.512^{\star \star}$ & $0.577^{\star \star}$ & $0.572^{\star \star}$ \\
\hline
\end{tabular}

$* 0<0.010$. 
TABLE 7 | Descriptive statistics of operational stress, distress and burnout.

\begin{tabular}{|c|c|c|c|c|}
\hline Scales (range) & Minimum & Maximum & Mean & Std. Deviation \\
\hline Work-related issues (1-7) & 1.00 & 7.00 & 4.648 & 1.496 \\
\hline Social-related issues & 1.00 & 7.00 & 5.246 & 1.318 \\
\hline Operational stress & 1.00 & 7.00 & 4.977 & 1.328 \\
\hline Enthusiasm (0-4) & 0.00 & 4.00 & 1.928 & 0.980 \\
\hline Psychological exhaustion & 0.00 & 4.00 & 2.379 & 1.067 \\
\hline Indolence & 0.00 & 4.00 & 2.231 & 0.987 \\
\hline Guilt & 0.00 & 4.00 & 0.858 & 0.715 \\
\hline Burnout & 0.00 & 4.00 & 1.877 & 0.723 \\
\hline Anxiety (4-20) & 4 & 20 & 9.784 & 3.938 \\
\hline Depression (6-30) & 6 & 30 & 14.463 & 6.160 \\
\hline Distress (10-50) & 10 & 50 & 24.246 & 9.743 \\
\hline
\end{tabular}

TABLE 8 | Sample's frequency (and percentage) distribution according established level (cut-off points).

\begin{tabular}{|c|c|c|c|c|c|}
\hline \multirow{2}{*}{$\begin{array}{l}\text { Questionnaires' scales } \\
\text { PSQ-Op }\end{array}$} & \multicolumn{5}{|c|}{ Established levels with cut-off points } \\
\hline & Low stress $(\leq 2)$ & Moderate stress (2.1-3.4) & High stress $(\geq 3.5)$ & & \\
\hline Work-related issues & $51(2.5)$ & $175(8.5)$ & $1831(89.0)$ & & \\
\hline Social-related issues & $121(5.9)$ & $368(17.9)$ & $1567(76.2)$ & & \\
\hline Operational stress & $56(2.7)$ & $257(12.5)$ & $1744(84.8)$ & & \\
\hline SBI & Very low level $(P \leq 10 \%)$ & Low (P11-33) & Moderate (P34-66) & High (P67-89) & Critical level $(P \geq 90)$ \\
\hline Enthusiasm & 219(10.6) & $520(25.3)$ & $701(34.1)$ & $420(20.4)$ & 197(9.6) \\
\hline Psychological exhaustion & $298(14.5)$ & $558(27.1)$ & 643(31.3) & $339(16.5)$ & 219(10.6) \\
\hline Indolence & $213(10.4)$ & $572(27.8)$ & $624(30.3)$ & $449(21.8)$ & $199(9.7)$ \\
\hline Guilt & $334(16.2)$ & $400(19.4)$ & $722(35.1)$ & 417 (20.3) & $184(8.9)$ \\
\hline Burnout & $231(11.2)$ & $479(23.3)$ & $676(32.9)$ & $450(21.9)$ & $221(10.7)$ \\
\hline K10 & Low stress (10-15) & Moderate stress (16-21) & High stress (22-29) & Very high stress $(30-50)$ & Risk of mental disorder $(22-50)$ \\
\hline Distress & $436(21.2)$ & $500(24.3)$ & $545(26.5)$ & 576(28) & $1121(54.5)$ \\
\hline
\end{tabular}

stress had a mean value of 3.32 , while the Portuguese sample presented values between 4.02 and 5.57 with operational stress having a mean value of 4.98 . Despite the difference between the time of data collection and cultural differences between the countries, given that the maximum value in the range is 7 points, the data suggest a higher level of stress among the Portuguese than the Canadian police officers. Summerlin et al. (2010) found high stress levels among American police officers for some operational tasks (e.g., $68 \%$ of the sample considered paperwork to be highly stressful and $73 \%$ considered handling the public image to be so), but other tasks were considered as highly stressful only for a few participants (e.g., $16 \%$ for activities during days off), while the Portuguese sample considered all tasks as either moderately or highly stressful. Bergman et al. (2016) reported mean values for operational stress among American police officers as 3.4, and 2.91 after a mindfulness intervention. Kaplan et al. (2017) reported mean values for operational stress (also among American police officers) as 3.47. All of these values are smaller than the Portuguese sample in the current study.

The sample presented moderate values for distress symptoms, but $28 \%$ of the sample presented very high distress levels, with $55 \%$ at risk of developing a psychological disorder. Additionally, the depression scale presented higher values than anxiety. As stated by the European Agency for Safety and Health at Work (EU-OSHA, 2018, 2019a,b), stress has become one of the most important psychosocial risks in the workplace, and it is crucial to develop measures to prevent it. Moreover, anxiety and depression are increasing (OECD, 2019) and are related to distress and burnout, which increases the difficulty of identifying and distinguishing these psychological problems (Bianchi et al., 2015; Golonka et al., 2019; Koutsimani et al., 2019; Bianchi, 2020).

The sample also presented moderate values for burnout, with Guilt having the lowest average, while Psychological Exhaustion and Indolence were higher. However, the analysis of cut-off points revealed that $11 \%$ of the sample presented critical values for Burnout, while values between 9 and $11 \%$ were found for other burnout dimensions. These values are less than those found by McCarty et al. (2019) who found that 19\% of a sample of American police officers suffered with emotional exhaustion and $13 \%$ with depersonalization. However, Gutshall et al. (2017) found moderate burnout levels for American police officers, whereas Solana et al. (2013) found high levels of burnout for Spanish police officers. As studies have revealed 
that burnout decreases self-protective behaviors and increases aggressive behaviors (Euwema et al., 2004; Queirós et al., 2013; Ellrich, 2016), it seems important to assess burnout levels on a regular basis.

Finally, analysis of the correlation between operational stress, distress, and burnout found that higher scores for operational stress, such as problems directly related to working conditions and the impact of work on family and social life, were associated with higher scores for other scales of distress and burnout. Furthermore, it seems that social-related issues interfere most with burnout and distress compared to work-related issues. This may be due to the fact that currently a police officer is not so well respected by society, especially when they are from a national police force that works in urban centers, such as the Portuguese police officers sampled in this study. This means that a large number of participants are away from their families and friends, working in large urban cities such as Lisbon or Oporto, and have difficulties receiving social support from their relatives. This situation contributes to a difficult balance between work and family, and Portugal is a country where professionals work more hours and have more work-family conflicts according to the OECD Better Life Index $2019^{10}$.

\section{CONCLUSION}

Burnout and stress among police officers has received increased attention from the scientific community and society, due to the psychological suffering they inflict on the individual, but also because of their impact on the performance of police officers and their interactions with citizens, leading to the increased possibility of all interactions being considered a threat, or to a tendency to use excessive force. Thus, it is crucial to develop stress management interventions (Patterson et al., 2014) and resilience interventions focused on policing specificities, such as those developed by projects like BCOPS (Wirth et al., 2017), HEROES (Thornton et al., 2020), POWER (Papazoglou and Blumberg, 2019), or POLICE (Trombka et al., 2018). However, before implementing an intervention, we need to identify burnout and stress levels, both in the early and later stages of a career. This implies a regular assessment of police officers and will be made easier if short and specific instruments are available and validated for policing stressors. Moreover, occupational health has become a concern, along with the need to identify critical situations early that might, without intervention, lead to situations that are more dangerous. Training mental strength, resilience, or emotional intelligence seems to be a possibility (Papazoglou and Andersen, 2014; Meulen et al., 2017; Romosiou et al., 2018), as well as reflecting the work values of police officers (Basinska and Daderman, 2019), since motivations for becoming a police officer have changed in recent decades (Lester, 1983; White et al., 2010). Furthermore, according to Blumberg et al. (2019, p. 1), new directions should be taken in police academy

${ }^{10}$ https://stats.oecd.org/Index.aspx?DataSetCode=BLI. training, preparing police officers "to meet the contemporary challenges of police work," and also to develop psychological skills, such as by including in the curricula stress prevention and management programs, as well as topics such as the stressburnout relationship.

Psychological suffering among police officers can be expressed to others through disengagement or cynical behavior, or impact on the self in the form of depression, sometimes leading to suicide. In fact, suicide among police has become a serious problem and is commonly carried out with the service handgun (Costa et al., 2019). Discussing the current study can help to increase awareness of psychological problems, especially those that are chronic and may result in burnout, and also to reduce burnout stigma and the stigma to seek help (Endriulaitiene et al., 2019). The results highlight the importance of occupational health services in risk prevention and the recovery of workers who play a crucial role in society, such as police officers who deal with safety and security at a national level. Studies that seek to identify police officers' stress and burnout levels must be continued and will contribute to identifying the risk and protective factors that influence a person's well-being, quality of life, job performance, and mental health, and also their families and the beneficiaries of police services (society and citizens).

\section{Theoretical Implications}

This study highlights the need to continue research on burnout and stress among police officers to develop our understanding of specific police stressors, such as those evaluated by the PSQ-Op. The literature review reinforces the importance of developing psychological instruments focused on policing tasks, while the data of the sample allow us to verify the relationship between job stress, stress symptoms, and burnout, which present moderate to strong correlations, suggesting they are independent constructs. Furthermore, these results can contribute to scientific research on police forces, a topic that has received increased attention globally, with a particular focus on the causes of stress and burnout. Both the World Health Organization and the European Agency for Safety and Health at Work have highlighted the need to prevent and manage job stress and to valorize mental health in the workplace, as well as the need to view burnout as an occupational phenomenon that must be considered among other psychosocial risks at work.

\section{Practical Implications}

This study provides preliminary data for the Portuguese version of the Police Stress Questionnaire, which presents adequate psychometric properties. Being a short measure, it can be used easily in the future to identify early police officers at risk of developing psychological problems, since occupational stress is related to burnout as an inadequate method of managing chronic job stress. This study used data from a large sample of Portuguese police officers, representing $10 \%$ of the entire national force, and the results can be used to identify stress and burnout levels before implementing intervention programs. Additionally, the literature review can be used to identify scientific studies that have assessed 
stress and burnout among police officers using questionnaires. These kinds of studies can contribute to reducing the stigma of seeking help when police officers confirm that a large number of colleagues are experiencing the same symptoms and difficulties.

\section{Limitations}

In the literature review, the search was focused on studies using questionnaires. This does not reflect all studies of police stress and burnout, which have increased enormously in the last decade. Moreover, the review did not consider post-traumatic stress, which can occur among professionals such as police officers who work in dangerous situations and frequently face critical incidents that can be potentially traumatic. Regarding data collection, the sample came from only one of the Portuguese police forces (called Polícia de Segurança Pública, a civil force). Despite the data being a national sample, no data were collected from police officers working in rural areas (from a militarized force called Guarda Nacional Republicana), or from a judicial/criminal force (called Polícia Judicária), which together comprise the three major Portuguese police forces. Furthermore, data analysis focused on the psychometric properties of the PSQ-Op and on stress/burnout identification levels. The analyses did not compare individual and professional characteristics such as age, gender, or career position. It is worth noting that the meta-analysis of Aguayo et al. (2017) found that sociodemographic factors can be associated with police officers' burnout.

\section{Future Research}

It will be important in future research to include samples from other Portuguese police forces to verify the invariance of PSQ-Op structure and validity. It will also be necessary to analyze the organizational stressors, which form the second part of the Police Stress Questionnaire. Moreover, the impact of individual and professional characteristics on stress and burnout must be considered, since the literature frequently suggests that different genders deal differently with emotions and stressors, with women feeling more emotional exhaustion, whereas men feel more disengagement, depersonalization, or indolence, and react differently to shift work (Violanti et al., 2018). Additionally, other psychological variables such as coping and resilience must be included, since they can affect stress responses and the process of stress and burnout development (Allison et al., 2019).

\section{REFERENCES}

Adams, I., and Mastracci, S. (2019). Police body-worn cameras: effects on officers' burnout and perceived organizational support. Police Q. 22, 5-30. doi: 10.1177/ 1098611118783987

Agolla, J. E. (2009). Occupational stress among police officers: the case of botswana police service. Res. J. Bus. Manag. 3, 25-35. doi: 10.3923/rjbm.2009.25.35

Aguayo, R., Vargas, C., Cañadas, G. R., and Fuente, E. I. (2017). Are sociodemographic factors associated to burnout syndrome in police officers? A correlational meta-analysis. An. Psicol. 33, 383-392. doi: 10.6018/analesps.33. 2.260391

\section{DATA AVAILABILITY STATEMENT}

The datasets generated for this study are available on request to the corresponding author, after National Portuguese Police authorization.

\section{ETHICS STATEMENT}

This study was carried out in accordance with the recommendations of the Ethics guidelines of the FPCEUP Ethics Committee, having online informed consent from all participants in accordance with the Declaration of Helsinki. The study was approved by the Portuguese National Police.

\section{AUTHOR CONTRIBUTIONS}

CQ, FP, AP, and CS designed the study. CQ and FP developed the theoretical framework. CQ and AM performed the literature review. $\mathrm{AB}, \mathrm{AP}$, and $\mathrm{CQ}$ performed the statistical analyses. All authors participated in results' discussion and final version of the manuscript. All authors of this research manuscript have directly participated in the planning, execution, and analysis of this study.

\section{FUNDING}

This work was funded by the Center for Psychology at the University of Porto, Portuguese Science Foundation (FCT UID/PSI/00050/2013) and EU FEDER through COMPETE 2020 program (POCI-01-0145-FEDER-007294).

\section{ACKNOWLEDGMENTS}

We wish to reinforce there are several acknowledgements Directorate of Portuguese National Police who approved and disseminated the study; all police officers of the PSP (from the first professional positions through to the high commanders) who generously spent their time participating in and disseminating the study, allowing us to collect data from a national sample; Professor Pedro Gil-Monte and TEA Ediciones, Spain, who authorized the use of SBI Portuguese version; and Sara Faria and Sílvia Monteiro Fonseca, who helped with the literature search, its organization, and preliminary analysis.

Alberti, J. M., Niñerola, J., Figueras, A., Higueras, E., Gutiérrez, M., Melero, A., et al. (2016). Burnout symptoms can be predicted by personality traits and psychopathology in a sample of Catalan police officers. Pers. Individ. Diff. 101:516. doi: 10.1016/j.paid.2016. 05.302

Albuerne, M., Nieto, M., and Moreno, L. (2015). Turnos y estrés psicosocial en los policías locales de Madrid. Ansiedad Estres 21, 57-70.

Allison, P., Mnatsakanova, A., McCanlies, E., Fekedulegn, D., Hartley, T. A., Andrew, M. E., et al. (2019). Police stress and depressive symptoms: role of coping and hardiness. Policing Int. J. [Epub ahead of Print]. doi: 10.1108/ pijpsm-04-2019-0055 
Almeida, D. M., Lopes, L. F., Costa, V. M., and Santos, R. T. (2018). Policiais militares do estado do rs: relação entre satisfação no trabalho e estresse ocupacional. Admin. Públ. Gestão Soc. 10, 55-65. doi: 10.21118/apgs.v10i1.1366

Andrews, G., and Slade, T. (2001). Interpreting scores on the kessler psychological distress scale (K10). Austral. New Zeal. J. Public Health 25, 494-497. doi: 10. 1111/j.1467-842x.2001.tb00310.x

Anshel, M. H., and Brinthaupt, T. M. (2014). An exploratory study on the effect of an approach-avoidance coping program on perceived stress and physical energy among police officers. Psychology 5, 676-687. doi: 10.4236/psych.2014.57079

Anson, R. H., Johnson, B., and Anson, N. W. (1997). Magnitude and source of general and occupation-specific stress among police and correctional officers. J. Off. Rehabil. 25, 103-113. doi: 10.1300/J076v25n01_07

Antoniou, A. S. (2009). Occupation-specific precursors of stress among greek police officers: the roles of rank and gender. Int. J. Police Sci. Manag. 11, 334-344. doi: 10.1350/ijps.2009.11.3.136

Arnetz, B. B., Arble, E., Backman, L., Lynch, A., and Lublin, A. (2013). Assessment of a prevention program for work-related stress among urban police officers. Int. Arch. Occup. Environ. Health 86, 79-88. doi: 10.1007/s00420-012-0748-6

Baka, L. (2015). The effects of job demands on mental and physical health in the group of police officers. Testing the mediating role of job burnout. Stud. Psychol. 57, 285-299. doi: 10.21909/sp.2015.03.700

Bakker, A. B., and Heuven, E. (2006). Emotional dissonance, burnout, and in-role performance among nurses and police officers. Int. J. Stress Manag. 13, 423-440. doi: 10.1037/1072-5245.13.4.423

Baldwin, S., Bennell, C., Andersen, J. P., Semple, T., and Jenkins, B. (2019). Stress-activity mapping: physiological responses during general duty police encounters. Front. Psychol. 10:2216. doi: 10.3389/fpsyg.2019.02216

Basinska, B. A., and Daderman, A. M. (2019). Work values of police officers and their relationship with job burnout and work engagement. Front. Psychol. 10:442. doi: 10.3389/fpsyg.2019.00442

Basinska, B. A., and Wiciak, I. (2012). Fatigue and professional burnout in police officers and firefighters. Intern. Security 4, 267-275.

Basinska, B. A., Wiciak, I., and Daderman, A. M. (2014). Fatigue and burnout in police officers: the mediating role of emotions. Policing Int. J. Police Strateg. Manag. 37, 665-680. doi: 10.1108/pijpsm-10-2013-0105

Bergman, A. L., Christopher, M. S., and Bowen, S. (2016). Changes in facets of mindfulness predict stress and anger outcomes for police officers. Mindfulness 7, 851-858. doi: 10.1007/s12671-016-0522-Z

Bertilsson, J., Niehorster, D., Fredriksson, P., Dahl, M., Granér, S., Fredriksson, O., et al. (2019). Towards systematic and objective evaluation of police officer performance in stressful situations. Police Pract. Res. 5, 1-15. doi: 10.1080/ 15614263.2019.1666006

Bianchi, R. (2020). Do burnout and depressive symptoms form a single syndrome? Confirmatory factor analysis and exploratory structural equation modeling bifactor analysis. J. Psychos. Res. 131:109954. doi: 10.1016/j.jpsychores.2020. 109954

Bianchi, R., Schonfeld, I. S., and Laurent, E. (2015). Is it time to consider the "burnout syndrome" a distinct illness? Front. Public Health 3:158. doi: 10.3389/ fpubh.2015.00158

Blazina, B. (2017). The characteristics of suicide among Slovene Police officers over the past seven decades. Rev. Kriminalistiko Kriminologijo 68, 333-358.

Blumberg, D. M., Schlosser, M. D., Papazoglou, K., Creighton, S., and Kaye, C. C. (2019). New directions in police academy training: a call to action. Int. J. Environ. Res. Public Health 16:4941. doi: 10.3390/ijerph16244941

Bollen, K. A., and Stine, R. A. (1992). Bootstrapping goodness-of-fit measures in structural equation models. Sociol. Methods Res. 21, 205-229. doi: 10.1177/ 0049124192021002004

Bong, M., Woo, Y., and Shin, J. (2013). Do students distinguish between different types of performance goals? J. Exp. Educ. 81, 464-489. doi: 10.1080/00220973. 2012.745464

Brown, J., and Cooper, C. (1996). Occupational stress among senior police officers. Br. J. Psychol. 87, 31-41. doi: 10.1111/j.2044-8295.1996.tb02575.x

Brown, J., and Fielding, J. (1993). Qualitative differences in men and women police officers' experience of occupational stress. Work Stress 7, 327-340. doi: 10.1080/02678379308257072

Brown, J. M., and Campbell, E. A. (1994). Stress and Policing: Sources and Strategies. Chichester: John Wiley \& Sons.
Burke, R. J. (1993). Work-family stress, conflict, coping, and burnout in police officers. Stress Med. 9, 171-180. doi: 10.1002/smi.2460090308

Burke, R. J. (1994). Stressful events, work-family conflict, coping, psychological burnout, and well-being among police officers. Psychol. Rep. 75, 787-800. doi: 10.2466/pr0.1994.75.2.787

Burke, R. J., and Deszca, E. (1986). Correlates of psychological burnout phases among police officers. Hum. Relat. 39, 487-501. doi: 10.1177/ 001872678603900601

Burke, R. J., and Mikkelsen, A. (2005). Burnout, job stress and attitudes towards the use of force by Norwegian police officers. Policing 28, 269-278. doi: 10.1108/ 13639510510597906

Burke, R. J., and Mikkelsen, A. (2006). Burnout among norwegian police officers: potential antecedents and consequences. Int. J. Stress Manag. 13, 64-83. doi: 10.1037/1072-5245.13.1.64

Burke, R. J., Shearer, J., and Deszca, E. (1984). Correlates of burnout phases among police officers. Group Organ. Manag. 9, 451-466. doi: 10.1177/ 105960118400900403

Byrne, B. M. (2016). Structural Equation Modelling with AMOS: Basic Concepts, Applications and Programming, 3rd Edn. Abingdon: Routledge.

Carvalho, A. L., Cury, A., and Garcia, R. (2008). Prevalence of bruxism and emotional stress and the association between them in Brazilian police officers. Braz. Oral Res. 22, 31-35. doi: 10.1590/S1806-83242008000100006

Castro, M. C., Rocha, R., and Cruz, R. (2019). Mental health of the Brazilian police policy: theoretical-methodological trends. Psicol. Saúde Doença 20, 525-541. doi: $10.15309 / 19$ psd200220

Charles, E., Slaven, E., Mnatsakanova, A., Ma, C., Violanti, J., Fekedulegn, D., et al. (2011). Association of perceived stress with sleep duration and sleep quality in police officers. Int. J. Emerg. Ment. Health 13, 229-242.

Chen, Y. F. (2009). Job stress and performance: a study of police officers in central Taiwan. Soc. Behav. Pers. 37, 1341-1356. doi: 10.2224/sbp.2009.37.10.1341

Chirico, F. (2016). Job stress models for predicting burnout syndrome: a review. Ann. Dell'Istituto Super. Sanita 52, 443-456. doi: 10.4415/ANN_16_03_17

Chitra, T., and Karunanidhi, S. (2018). The impact of resilience training on occupational stress, resilience, job satisfaction, and psychological well-being of female police officers. J. Police Criminal Psychol. 3, 1-16. doi: 10.1007/s11896018-9294-9

Chongruksa, D., Parinyapol, P., Sawatsri, S., and Pansomboon, C. (2012). Efficacy of eclectic group counseling in addressing stress among Thai police officers in terrorist situations. Counsel. Psychol. Q. 25, 83-96. doi: 10.1080/09515070.2012. 666424

Collins, P. A., and Gibbs, A. (2003). Stress in police officers: a study of the origins, prevalence and severity of stress-related symptoms within a county police force. Occup. Med. 53, 256-264. doi: 10.1093/occmed/kqg061

Costa, T., Passos, F., and Queirós, C. (2019). Suicides of male Portuguese police officers - 10 years of national data. Crisis 40, 360-364. doi: 10.1027/0227-5910/ a000570

Couto, G., Vandenberghe, L., and Brito, E. (2012). Interações interpessoais e estresse entre policiais. Arq. Bras. Psicol. 64, 47-63.

Cumming, E., Cumming, I., and Edell, L. (1965). Policeman as philosopher, guide and friend. Soc Probl. 12, 276-286. doi: 10.2307/798933

Daderman, A., and Colli, D. (2014). The significance of the sense of coherence for various coping resources in stress situations used by police officers in on-thebeat service. Int. J. Occup. Med. Environ. Health 27, 3-15. doi: 10.2478/s13382014-0227-2

Ellrich, K. (2016). Burnout and violent victimization in police officers: a dual process model. Policing 39, 652-666. doi: 10.1108/PIJPSM-10-2015-0125

Endriulaitiene, A., Zardeckaite-Matulaitiene, K., Pranckeviciene, A., Marksaityte, R., Tillman, D. R., and Hof, D. D. (2019). Self-Stigma of seeking help and job burnout in mental health care providers: the comparative study of Lithuanian and the USA samples. J. Workplace Behav. Health 34, 1-20. doi: 10.1080/ 15555240.2019.1586549

Ermasova, N., Cross, A. D., and Ermasova, E. (2020). Perceived stress and coping among law enforcement officers: an empirical analysis of patrol versus nonpatrol officers in illinois, USA. J. Police Crim. Psychol. doi: 10.1007/s11896-01909356-Z

EU-OSHA (2018). Healthy Workers, Thriving Companies - A Practical Guide to Wellbeing at Work. Luxembourg: Publications Office of the European Union. 
EU-OSHA (2019a). The Value of Occupational Safety and Health and the Societal Costs of Work-Related Injuries and Diseases. Luxembourg: Publications Office of the European Union.

EU-OSHA (2019b). Third European Survey of Enterprises on New and Emerging Risks (ESENER-3). Luxembourg: Publications Office of the European Union.

EUROFOUND (2018). Burnout in the Workplace: A Review of Data and Policy Responses in the EU. Luxembourg: Publications Office of the European Union.

Euwema, M. C., Kop, N., and Bakker, A. B. (2004). The behavior of police officers in conflict situations: how burnout and reduced dominance contribute to better outcomes. Work Stress 18, 23-38. doi: 10.1080/0267837042000209767

Figueiredo-Ferraz, H., Gil-Monte, P. R., Queirós, C., and Passos, F. (2014). Validação fatorial do "Spanish Burnout Inventory" em policiais portugueses. Psicol. Reflexão Crit. 27, 291-299. doi: 10.1590/1678-7153.201427209

Freudenberger, H. J. (1974). Staff burn-out. J. Soc. Issues 30, 159-165. doi: 10.1111/ j.1540-4560.1974.tb00706.x

Garbarino, S., Cuomo, G., Chiorri, C., and Magnavita, N. (2013). Association of work-related stress with mental health problems in a special police force unit. BMJ Open 3, 1-12. doi: 10.1136/bmjopen-2013-002791

Garbarino, S., and Magnavita, N. (2019). Sleep problems are a strong predictor of stress-related metabolic changes in police officers. A prospective study. PLoS One 14:e0224259. doi: 10.1371/journal.pone.0224259

Gerber, M., Hartmann, T., Brand, S., Holsboer-Trachsler, E., and Pühse, U. (2010a). The relationship between shift work, perceived stress, sleep and health in Swiss police officers. J. Crim. Just. 38, 1167-1175. doi: 10.1016/j.jcrimjus.2010.09.005

Gerber, M., Kellmann, M., Hartmann, T., and Pühse, U. (2010b). Do exercise and fitness buffer against stress among Swiss police and emergency response service officers? Psychol. Sport Exerc. 11, 286-294. doi: 10.1016/j.psychsport.2010. 02.004

Gershon, R., Barocas, B., Canton, A. N., Xianbin, L., and Vlahov, D. (2009). Mental, physical, and behavioral outcomes associated with perceived work stress in police officers. Crim. Just. Behav. 36, 275-289. doi: 10.1177/0093854808330015

Gil-Monte, P. R. (2011). CESQT, Cuestionario Para la Evaluación del Síndrome de Quemarse Por el Trabajo [Spanish Burnout Inventory]. Madrid: TEA Ediciones.

Gil-Monte, P. R., and Manzano-García, G. (2015). Psychometric properties of the Spanish Burnout Inventory among staff nurses. J. Psychiatr. Ment. Health Nurs. 22, 756-763. doi: 10.1111/jpm.12255

Golonka, K., Mojsa-Kaja, J., Blukacz, M., Gawłowska, M., and Marek, T. (2019). Occupational burnout and its overlapping effect with depression and anxiety. Int. J. Occup. Med. Environ. Health 32, 229-244. doi: 10.13075/ijomeh.1896. 01323

Gomes, A. R., and Afonso, J. M. P. (2016). Occupational stress among Portuguese military police officers. Avances Psicol. Latinoam. 34, 47-65. doi: 10.12804/ apl34.1.2016.04

Goodman, A. M. (1990). A model for police officer burnout. J. Bus. Psychol. 5, 85-99. doi: 10.1007/BF01013947

Grassi, C., Casale, A., Ferracuti, S., Cucè, P., Santorsa, R., Pelliccione, A., et al. (2018). How do recruits and superintendents perceive the problem of suicide in the Italian state police? Ann. Dell'Istituto Super. Sanita 54, 82-89. doi: 10. 4415/ANN_18_02_02

Griffin, J. D., and Sun, I. Y. (2018). Do work-family conflict and resiliency mediate police stress and burnout: a study of state police officers. Am. J. Crim. Just. 43, 354-370. doi: 10.1007/s12103-017-9401-y

Gutshall, C. L., Hampton, D. P., Sebetan, I. M., Stein, P. C., and Broxtermann, T. J. (2017). The effects of occupational stress on cognitive performance in police officers. Police Pract. Res. 18, 463-477. doi: 10.1080/15614263.2017.1288120

Hartley, T. A., Violanti, J. M., Mnatsakanova, A., and Andrew, M. E. (2013). Military experience and levels of stress and coping in police officers. Int. J. Emerg. Ment. Health Hum. Resil. 15, 229-239.

Hassell, K. D., Archbold, C. A., and Stichman, A. J. (2011). Comparing the workplace experiences of male and female police officers: examining workplace problems, stress, job satisfaction and consideration of career change. Int. J. Police Sci. Manag. 13, 37-53. doi: 10.1350/ijps.2011.13.1.217

Hawkins, H. C. (2001). Police officer burnout: a partial replication of Maslach's burnout inventory. Police Q. 4, 343-360. doi: 10.1177/109861101129197888

Henry, V. E. (2004). Death Work: Police, Trauma, and The Psychology of Survival. Oxford: Oxford University Press.

Hickman, M. J., Fricas, J., Strom, K. J., and Pope, M. W. (2011). Mapping police stress. Police Q. 14, 227-250. doi: 10.1177/1098611111413991
Houdmont, J. (2013). UK police custody officers' psychosocial hazard exposures and burnout. Policing 36, 620-635. doi: 10.1108/pijpsm-11-2012-0109

Hu, Q., Schaufeli, W. B., and Taris, T. W. (2017). How are changes in exposure to job demands and job resources related to burnout and engagement? A longitudinal study among Chinese nurses and police officers. Stress Health J. Int. Soc. Investig. Stress 33, 631-644. doi: 10.1002/smi.2750

Hurrell, J. J., Pate, A., and Kliesmet, R. (1984). NIOSH Technical Report: Stress Among Police Officers. Ohio: US Departement of Health and Human Services.

Husain, W., Sajjad, R., and Rehman, A. (2014). Depression, anxiety and stress among female and male police officers. Pakistan J. Clin. Psychol. 13, 3-14.

Irniza, R., Emilia, Z. A., Saliluddin, S. M., and Isha, A. S. N. (2014). A psychometric properties of the Malay-version police stress questionnaire. Malays. J. Med. Sci. 21, 42-50.

Johnson, O., Russo, C., and Papazoglou, K. (2019). Job exposure \& occupational challenges: the importance of mindfulness for today's law enforcement professional. Crisis Stress Hum. Resil. Int. J. 1, 187-191.

Kaplan, J. B., Christopher, M. S., and Bowen, S. (2017). Dispositional mindfulness moderates the relationship between occupational stressors and perceived stress among law enforcement personnel. J. Police Crim. Psychol. 33, 227-232. doi: 10.1007/s11896-017-9246-9

Kelley, D. C., Siegel, E. H., and Wormwood, J. B. (2019). Understanding police performance under stress: insights from the biopsychosocial model of challenge and threat. Front. Psychol. 10:1800. doi: 10.3389/fpsyg.2019.01800

Kelloway, E. K. (1995). Structural equation modeling in perspective. J. Organ. Behav. 16, 215-224. doi: 10.1002/job.4030160304

Kessler, R. C., Andrews, G., Colpe, L. J., Hiripi, E., Mroczek, D. K., Normand, S. L. T., et al. (2002). Short screening scales to monitor population prevalences and trends in non-specific psychological distress. Psychol. Med. 32, 959-976. doi: 10.1017/s0033291702006074

Kessler, R. C., Barker, P. R., Colpe, L. J., Epstein, J. F., Gfroerer, J. C., Hiripi, E., et al. (2003). Screening for serious mental illness in the general population. Arch. Gen. Psychiatry 60, 184-189.

Kirkcaldy, B. (1993). Job stress and satisfaction: international police officers. Psychol. Rep. 72:386. doi: 10.2466/pr0.1993.72.2.386

Kirkcaldy, B. D., Brown, J., and Cooper, C. L. (1994). Occupational stress profiles of senior police managers: cross-cultural study of officers from Berlin and northern Ireland. Stress Med. 10, 127-130. doi: 10.1002/smi.2460100209

Kirkcaldy, B. D., and Cooper, C. L. (1992). Managing the stress of change: occupational stress among senior police officers in Berlin. Stress Med. 8, 219231. doi: $10.1002 /$ smi.2460080404

Kirkcaldy, B. D., Cooper, C. L., and Brown, J. M. (1995). The role of coping in the stress-strain relationship among senior police officers. Int. J. Stress Manag. 2, 69-78. doi: 10.1007/bf01566162

Kline, R. (2005). Principles and Practice of Structural Equation Modeling, 2nd Edn. New York, NY: Guilford.

Kop, N., Euwema, M., and Schaufeli, W. (1999). Burnout, job stress and violent behaviour among Dutch police officers. Work Stress 13, 326-340. doi: 10.1080/ 02678379950019789

Kop, N., and Euwema, M. C. (2001). Occupational stress and the use of force by Dutch police officers. Crim. Just. Behav. 28, 631-652. doi: 10.1177/ 009385480102800505

Korre, M., Farioli, A., Varvarigou, V., Sato, S., and Kales, S. N. (2014). A survey of stress levels and time spent across law enforcement duties: police chief and officer agreement. Policing 8, 109-122. doi: 10.1093/police/pau001

Koutsimani, P., Montgomery, A., and Georganta, K. (2019). The relationship between burnout, depression, and anxiety: a systematic review and metaanalysis. Front. Psychol. 10:284. doi: 10.3389/fpsyg.2019.00284

Kuo, S. Y. (2014). Occupational stress, job satisfaction, and affective commitment to policing among Taiwanese police officers. Police Q. 18, 27-54. doi: 10.1177/ 1098611114559039

Kwak, H., McNeeley, S., and Kim, S. H. (2018). Emotional labor, role characteristics, and police officer burnout in South Korea: the mediating effect of emotional dissonance. Police Q. 21, 223-249. doi: 10.1177/ 1098611118757230

Lambert, E. G., Qureshi, H., Frank, J., Klahm, C., and Smith, B. (2017). Job stress, job involvement, job satisfaction, and organizational commitment and their associations with job burnout among indian police officers: a research note. J. Police Crim. Psychol. 33, 85-99. doi: 10.1007/s11896-017-9236-y 
Lambert, E. G., Qureshi, H., Keena, L. D., Frank, J., and Hogan, N. L. (2019). Exploring the link between work-family conflict and job burnout among Indian police officers. Police J. 92, 35-55. doi: 10.1177/0032258X18761285

Lazaus, R., and Folkman, S. (1984). Stress Appraisal and Coping. New York, NY: Springer.

LeBlanc, V. R., Regehr, C., Jelley, R. B., and Barath, I. (2008). The relationship between coping styles, performance, and responses to stressful scenarios in police recruits. Int. J. Stress Manag. 15, 76-93. doi: 10.1037/1072-5245.15.1.76

Lester, D. (1982a). Perceived stress in police officers and belief in locus of control. J. Gen. Psychol. 107, 157-158. doi: 10.1080/00221309.1982.9709918

Lester, D. (1982b). Subjective stress and sources of stress for police officers. Psychol. Rep. 50:1094. doi: 10.2466/pr0.1982.50.3c.1094

Lester, D. (1983). Why do people become police officers: a study of reasons and their predictions of success. J. Police Sci. Admin. 11, 170-174.

Lester, D., Leitner, L. A., and Posner, I. (1984). The effects of a stress management training program on police officers. Appl. Psychol. 33, 25-31. doi: 10.1111/j. 1464-0597.1984.tb01414.x

Lester, D., Leitner, L. A., and Posner, I. (1985). A note on locus of control and stress in police officers. J. Commun. Psychol. 13, 77-79. doi: 10.1002/15206629(198501)13:1<77::AID-JCOP2290130110<3.0.CO;2-T

Lester, D., and Mink, S. R. (1979). Is stress higher in police officers? An exploratory study. Psychol. Rep. 45:554. doi: 10.2466/pr0.1979.45.2.554

Lester, D., and Solis, A. (1980). Type a personality, stress, and job satisfaction in police officers. Percept. Mot. Skills 51:890. doi: 10.2466/pms.1980.51.3.890

Levitov, J. E., and Thompson, B. (1981). Stress and counseling needs of police officers. Couns. Educ. Supervis. 21, 163-168. doi: 10.1002/j.1556-6978.1981. tb01686.x

Lima, F. R., Ferreira Lima, D. L., Ramos de Oliveira, A. A., Ferreira, E., and Neto, P. (2018). Identificação preliminar da síndrome de burnout em policiais militares. Motricidade 14, 150-156.

Lin, Q., Jiang, C., and Lam, T. H. (2013). The relationship between occupational stress, burnout, and turnover intention among managerial staff from a sinoJapanese joint venture in Guangzhou, China. J. Occup. Health 55, 458-467. doi: 10.1539/joh.12-0287-oa

Lipp, M. E. (2009). Stress and quality of life of senior Brazilian police officers. Span. J. Psychol. 12, 593-603. doi: 10.1017/\$1138741600001967

Lipp, M. E., Costa, K. R., and Nunes, V. (2017). Estresse, qualidade de vida e estressores ocupacionais de policiais: sintomas mais frequentes. Rev. Psicol. Organ. Trabalho 17, 46-53. doi: 10.17652/rpot/2017.1.12490

Louw, G. J. (2014). Burnout, vigor, big five personality traits and social support in a sample of police officers. S. Afr. J. Ind. Psychol. 40, 1-13. doi: 10.4102/sajip. v40i1.1119

Lucas, T., Weidner, N., and Janisse, J. (2012). Where does work stress come from? A generalizability analysis of stress in police officers. Psychol. Health 27, 1426-1447. doi: 10.1080/08870446.2012.687738

Luceño-Moreno, L., Albuerne, Y., Velasco, B., and García, J. (2016). Estrés en policías españoles según rango ocupacional, sexo, edad y turno de trabajo. Psicothema 28, 389-393. doi: 10.7334/psicothema2015.310

Magnavita, N., Capitanelli, I., Garbarino, S., and Pira, E. (2018). Work-related stress as a cardiovascular risk factor in police officers: a systematic review of evidence. Int. Arch. Occup. Environ. Health 91, 377-389. doi: 10.1007/s00420018-1290-y

Maran, D., Varetto, A., Zedda, M., and Ieraci, V. (2015). Occupational stress, anxiety and coping strategies in police officers. Occup. Med. 65, 466-473. doi: 10.1093/occmed/kqv060

Maria, A. S., Wolter, C., Gusy, B., Kleiber, D., and Renneberg, B. (2019). The impact of health-oriented leadership on police officers' physical health, burnout, depression and well-being. Policing 13, 186-200. doi: 10.1093/police/pay067

Maroco, J. (2014). Análise de Equações Estruturais: Fundamentos Teóricos, Software e Aplicações, 2nd Edn. Pero Pinheiro: ReportNumber.

Martinussen, M., Richardsen, A. M., and Burke, R. J. (2007). Job demands, job resources, and burnout among police officers. J. Crim. Just. 35, 239-249. doi: 10.1016/j.jcrimjus.2007.03.001

Maslach, C. (1976). Burned-out. Hum. Behav. 5, 16-22.

Maslach, C. (2017). Finding solutions to the problem of burnout. Consul. Psychol. J. Pract. Res. 69, 143-152. doi: 10.1037/cpb0000090

Maslach, C., and Jackson, S. (1981). The measurement of experienced burnout. J. Occup. Behav. 2, 99-111.
Maslach, C., and Leiter, M. P. (2016). Understanding the burnout experience: recent research and its implications for psychiatry. World Psychiatry 15, 1-9. doi: 10.1002/wps.20311

Maslach, C., and Leiter, M. P. (2017). Understanding Burnout. Handb. Stress Health 51, 36-56. doi: 10.1002/9781118993811.ch3

Maslach, C., Schaufeli, W. B., and Leiter, M. P. (2001). Job burnout. Annu. Rev. Psychol. 52, 397-422.

Mastracci, S. H., and Adams, I. T. (2019). It's not depersonalization, It's emotional labor: examining surface acting and use-of-force with evidence from the US. Int. J. Law Crime Just. 2019:100358. doi: 10.1016/J.IJLCJ.2019.100358

McCarty, W. P., Aldirawi, H., Dewald, S., and Palacios, M. (2019). Burnout in blue: an analysis of the extent and primary predictors of burnout among law enforcement officers in the United States. Police Q. 22, 278-304. doi: 10.1177/ 1098611119828038

McCarty, W. P., Solomon, Z. J., and Garland, B. E. (2007). Occupational stress and burnout between male and female police officers. Policing 30, 672-691. doi: 10.1108/13639510710833938

McCreary, D. R., Fong, I., and Groll, D. L. (2017). Measuring policing stress meaningfully: establishing norms and cut-off values for the Operational and Organizational Police Stress Questionnaires. Police Pract. Res. 18, 612-623. doi: 10.1080/15614263.2017.1363965

McCreary, D. R., and Thompson, M. M. (2004). The Development of a Reliable and Valid Measure of Stressors in Policing - A Summary of Findings from WSIB Development Grant \#02-051. Toronto: Defense R\&D Canada-Toronto.

McCreary, D. R., and Thompson, M. M. (2006). Development of two reliable and valid measures of stressors in policing: the operational and organizational police stress questionnaires. Int. J. Stress Manag. 13, 494-518. doi: 10.1037/1072-5245. 13.4.494

Meulen, E., Bosmans, M. W. G., Lens, K. M. E., Lahlah, E., and Velden, P. G. (2017). Effects of mental strength training for police officers: a three-wave quasiexperimental study. J. Police Crim. Psychol. 33, 385-397. doi: 10.1007/s11896017-9247-8

Neely, P., and Cleveland, C. S. (2011). The impact of job-related stressors on incidents of excessive force by police officers. Am. J. Health Sci. 3, 63-74. doi: 10.19030/ajhs.v3i1.6755

Nelson, K. V., and Smith, A. P. (2016). Occupational stress, coping and mental health in Jamaican police officers. Occup. Med. 66, 488-491. doi: 10.1093/ occmed/kqw055

Norvell, N. K., Hills, H. A., and Murrin, M. R. (1993). Understanding stress in female and male law enforcement officers. Psychol. Women Q. 17, 289-301. doi: 10.1111/j.1471-6402.1993.tb00488.x

OECD (2019). Health at Glance 2019, OECD Indicators. Paris: OECD Publishing.

Padyab, M., Backteman-Erlanson, S., and Brulin, C. (2016). Burnout, coping, stress of conscience and psychosocial work environment among patrolling police officers. J. Police Crim. Psychol. 31, 229-237. doi: 10.1007/s11896-015-9189-y

Papazoglou, K. (2016). Managing effective transitions: presenting the different shades of police life and the pivotal role of mental health care providers in promoting officers' wellbeing. Int. J. Med. Health Sci. 5, 121-122.

Papazoglou, K., and Andersen, J. P. (2014). A guide to utilizing police training as a tool to promote resilience and improve health outcomes among police officers. Traumatology 20, 103-111. doi: 10.1037/h0099394

Papazoglou, K., and Blumberg, D. M. (2019). POWER: Police Officer, Wellness, Ethics, and Resilience. Cambridge: Academic Press.

Papazoglou, K., Blumberg, D. M., Kamkar, K., Mc-Intyre-Smith, A., and Koskelainen, M. (2020). Addressing moral suffering in police work: theoretical conceptualization and counselling implications. Can. J. Counsel. Psychother. 54, 71-87.

Papazoglou, K., Koskelainen, M., and Stuewe, N. (2018). Exploring the role of compassion satisfaction and compassion fatigue in predicting burnout among police officers. Open J. Psychiatry Allied Sci. 9, 107-112. doi: 10.5958/23942061. 2018.00020.4

Papazoglou, K., Koskelainen, M., Tuttle, B. M., and Pitel, M. (2017). Examining the role of police compassion fatigue and negative personality traits in impeding the promotion of police compassion satisfaction: a brief report. J. Law Enforcement $6,1-14$.

Patel, R., Huggard, P., and Toledo, A. (2017). Occupational stress and burnout among surgeons in Fiji. Front. Public Health 5:41. doi: 10.3389/fpubh.2017. 00041 
Patterson, B. (1992). Job experience and perceived job stress among police, correctional, and probation/parole officers. Crim. Just. Behav. 19, 160-285. doi: 10.1177/0093854892019003004

Patterson, G. T. (2003). Examining the effects of coping and social support on work and life stress among police officers. J. Crim. Just. 31, 215-226. doi: 10.1016/s0047-2352(03)00003-5

Patterson, G. T., Chung, I. W., and Swan, P. W. (2014). Stress management interventions for police officers and recruits: a meta-analysis. J. Exp. Criminol. 10, 487-513. doi: 10.1007/s11292-014-9214-7

Peiró, J. M., González-Romá, V., Tordera, N., and Manas, M. A. (2001). Does role stress predict burnout over time among health care professionals? Psychol. Health 16, 511-525. doi: 10.1080/08870440108405524

Pelegrini, A., Cardoso, T., Laumann, G., Pinto, A., and Felden, E. P. (2018). Percepção das condições de trabalho e estresse ocupacional em policiais civis e militares de unidades de operações especiais. Cadernos Bras. Terapia Ocup. 26, 423-430. doi: 10.4322/2526-8910.ctoAO1160

Pereira, A., Oliveira, C. A., Bártolo, A., Monteiro, S., Vagos, P., and Jardim, J. (2019). Reliability and factor structure of the 10-item kessler psychological distress scale (K10) among Portuguese adults. Ciência Saúde Coletiva 24, 729-736. doi: 10.1590/1413-81232018243.06322017

Perez, L. M., Jones, J., Englert, D. R., and Sachau, D. (2010). Secondary traumatic stress and burnout among law enforcement investigators exposed to disturbing media images. J. Police Crim. Psychol. 25, 113-124. doi: 10.1007/s11896-0109066-7

Pines, A. M., and Keinan, G. (2005). Stress and burnout: the significant difference. Pers. Individ. Diff. 39, 625-635. doi: 10.1016/j.paid.2005.02.009

Pines, A. M., and Keinan, G. (2007). Stress and burnout in israeli police officers during a palestinian uprising (Intifada). Int. J. Stress Manag. 14, 160-174. doi: 10.1037/1072-5245.14.2.160

Poletto, N. A., Probst, L. F., Oliveira, T. L., Guerra, L. M., Ambrosano, G. M. B., Cortellazzi, K. L., et al. (2016). Burnout Syndrome in municipal health managers. Cadernos Saúde Coletiva 24, 209-215. doi: 10.1590/1414462X201600020005

Purba, A., and Demou, E. (2019). The relationship between organizational stressors and mental wellbeing within police officers: a systematic review. BMC Public Health 19:1286. doi: 10.1186/s12889-019-7609-0

Queirós, C., Kaiseler, M., and Silva, A. (2013). Burnout as predictor of aggressivity among police officers. Eur. J. Polic. Stud. 1, 110-134.

Quick, J., and Henderson, D. (2016). Occupational stress: preventing suffering, enhancing wellbeing. Int. J. Environ. Res. Public Health 13, 459-570. doi: 10. 3390/ijerph13050459

Ratner, B. (2009). The correlation coefficient: its values range between $+1 /-1$, or do they? J. Target. Meas. Anal. Mark. 17, 139-142. doi: 10.1057/jt.2009.5

Romosiou, V., Brouzos, A., and Vassilopoulos, S. P. (2018). An integrative group intervention for the enhancement of emotional intelligence, empathy, resilience and stress management among police officers. Police Pract. Res. 20, 460-478. doi: 10.1080/15614263.2018.1537847

Rosa, J., Passos, F., and Queirós, C. (2015). Um estudo exploratório sobre burnout e indicadores psicopatológicos em polícias. Int. J. Work. Condit. 10, 101-119. doi: 10.11606/s1518-8787.2020054000854

Roz, H. B., and Raval, D. T. (2017). A study of occupational stress, burnout, presumptive life events, depression and anxiety among Ahmedabad city police officers. Indian J. Health Wellbeing 8, 1485-1492.

Russell, L. M., Cole, B. M., and Jones, I. R. J. (2014). High-risk occupations: how leadership, stress, and ability to cope influence burnout in law enforcement. J. Leadersh. Accountabil. Ethics 11, 49-69.

Salvagioni, D. A. J., Melanda, F. N., Mesas, A. E., González, A. D., Gabani, F. L., and Andrade, S. M. (2017). Physical, psychological and occupational consequences of job burnout: a systematic review of prospective studies. PLoS One 12:e0185781. doi: 10.1371/journal.pone.01815781

Santana, A. M., Gomes, J. K., Marchi, D., Girondoli, Y. M., Rosado, L. E., Rosado, G. P., et al. (2012). Occupational stress, working condition and nutritional status of military police officers. Work 41, 2908-2914. doi: 10.3233/WOR-20120543-2908

Sarason, I. G., Johnson, J. H., Berberich, J. P., and Siegel, J. M. (1979). Helping police officers to cope with stress: a cognitive-behavioral approach. Am. J. Commun. Psychol. 7, 593-603. doi: 10.1007/BF00891964
Schaible, L. M., and Gecas, V. (2010). The impact of emotional labor and value dissonance on burnout among police officers. Police Q. 13, 316-341. doi: 10. $1177 / 1098611110373997$

Schaufeli, W. B. (2017). "Burnout: a short socio-cultural history," in Burnout, Fatigue, Exhaustion: An Interdisciplinary Perspective on a Modern Affliction, eds S. Neckel, A. K. Schaffner, and G. Wagner (London: Palgrave Macmillan), 105-127. doi: 10.1007/978-3-319-52887-8_5

Schilling, R., Colledge, F., Brand, S., Ludyga, S., and Gerber, M. (2019). Psychometric properties and convergent validity of the shirom-melamed burnout measure in two german-speaking samples of adult workers and police officers. Front. Psychiatry 10:536. doi: 10.3389/fpsyt.2019.00536

Schlichting, A. M. Jr., Silva, F. C., Bernardo, V. M., Gonçalves, E., Gutierres Filho, P. J., and Silva, R. (2014). The occupational stress affects the health conditions of military police officers. Rev. Cubana Med. Militar 43, 293-306.

Shane, J. M. (2010). Organizational stressors and police performance. J. Crim. Just. 38, 807-818. doi: 10.1016/j.jcrimjus.2010.05.008

Shipley, P., and Baranski, J. V. (2002). Police officer performance under stress: a pilot study on the effects of visuo-motor behavior rehearsal. Int. J. Stress Manag. 9, 71-80. doi: 10.1023/A:1014950602826

Silveira, N. M., Vasconcellos, S. J., Cruz, L. P., Kiles, R. F., Silva, T. P., Castilhos, D. G., et al. (2005). Assessment of burnout levels in a sample of police officers. Rev. Psiquiatria Rio Grande Sul 27, 159-163. doi: 10.1590/S010181082005000200006

Smoktunowicz, E., Baka, L., Cieslak, R., Nichols, C. F., Benight, C. C., and Luszczynska, A. (2015). Explaining counterproductive work behaviors among police officers: the indirect effects of job demands are mediated by job burnout and moderated by job control and social support. Hum. Perform. 28, 332-350. doi: 10.1080/08959285.2015.1021045

Solana, E. F., Extremera, R. A., Pecino, C. V., and Fuente, G. (2013). Prevalence and risk factors of burnout syndrome among Spanish police officers. Psicothema 25, 488-493. doi: 10.7334/psicothema2013.81

Stinchcomb, J. (2004). Searching for stress in all the wrong places. Police Pract. Res. 5, 259-277. doi: 10.1080/156142604200227594

Summerlin, Z., Oehme, K., Stern, N., and Valentine, C. (2010). Disparate levels of stress in police and correctional officers: preliminary evidence from a pilot study on domestic violence. J. Hum. Behav. Soc. Environ. 20, 762-777. doi: 10.1080/10911351003749169

Tabachnick, B. G., and Fidell, L. S. (2001). Using Multivariate Statistics, 4th Edn. Boston, MA: Allyn and Bacon.

Talavera-Velasco, B., Luceño-Moreno, L., Martín-García, J., and García-Albuerne, Y. (2018). Psychosocial risk factors, burnout and hardy personality as variables associated with mental health in police officers. Front. Psychol. 9:1478. doi: 10.3389/fpsyg.2018.01478

Tang, T., and Hammontree, M. (1992). The effects of hardiness, police stress, and life stress on police officers' Ilness and absenteeism. Public Pers. Manag. 21, 493-510. doi: 10.1177/009102609202100406

Tavares, J. P., and Lautert, L. (2017). Relationship between psychosocial stress dimensions and salivary cortisol in military police officers. Rev. Latino Am. Enfermagem 25, 1-9. doi: 10.1590/1518-8345.1199.2873

Thornton, A. R., Blumberg, D. M., Papazoglou, K., and Giromini, L. (2020). “The HEROES project: mental health intervention and treatment of first responders and emergency workers," in Mental Health Intervention and Treatment of First Responders and Emergency Workers, eds C. A. Bowers, D. C. Beidel, and M. R. Marks (Pennsylvania: IGI Global), 154-168. doi: 10.4018/978-1-5225-9803-9. ch009

Trombka, M., Demarzo, M., Bacas, D. C., Antonio, S. B., Cicuto, K., Salvo, V., et al. (2018). Study protocol of a multicenter randomized controlled trial of mindfulness training to reduce burnout and promote quality of life in police officers: the POLICE study. BMC Psychiatry 18:151. doi: 10.1186/s12888-0181726-7

van Gelderen, B., Heuven, E., Veldhoven, M., Zeelenberg, M., and Croon, M. (2007). Psychological strain and emotional labor among police-officers: a diary study. J. Vocat. Behav. 71, 446-459. doi: 10.1016/j.jvb.2007.09.001

Violanti, J. M. (1996). Police Suicide: Epidemic in Blue. Springfield: Charles C Thomas.

Violanti, J. M., and Aron, F. (1995). Police stressors: variations in perception among police personnel. J. Crim. Just. 23, 287-294. doi: 10.1016/0047-2352(95)00012-f 
Violanti, J. M., Charles, L. E., McCanlies, E., Hartley, T. A., Baughman, P., Andrew, M. E., et al. (2017). Police stressors and health: a state-of-the-art review. Policing 40, 642-656. doi: 10.1108/PIJPSM-06-2016-0097

Violanti, J. M., Owens, S. L., Fekedulegn, D., Ma, C. C., Charles, L. E., and Andrew, M. E. (2018). An exploration of shift work, fatigue, and gender among police officers: the BCOPS study. Workplace Health Saf. 66, 530-537. doi: 10.1177/ 2165079918754586

Violanti, J. M., Owens, S. L., McCanlies, E., Fekedulegn, D., and Andrew, M. E. (2019). Law enforcement suicide: a review. Policing 42, 141-164. doi: 10.1108/ pijpsm-05-2017-0061

Vuorensyrja, M., and Malkia, M. (2011). Nonlinearity of the effects of police stressors on police officer burnout. Policing 34, 382-402. doi: 10.1108/ 13639511111157474

Wang, Z., Liu, H., Yu, H., Wu, Y., Chang, S., and Wang, L. (2017). Associations between occupational stress, burnout and well-being among manufacturing workers: mediating roles of psychological capital and self-esteem. BMC Psychiatry 17:364. doi: 10.1186/s12888-017-1533-6

Wassermann, A., Meiring, D., and Becker, J. R. (2019). Stress and coping of police officers in the South African police service. S. Afr. J. Psychol. 49, 97-108. doi: $10.1177 / 0081246318763059$

Webster, J. H. (2013). Police officer perceptions of occupational stress: the state of the art. Policing 36, 636-652. doi: 10.1108/pijpsm-03-2013-0021

White, J., Lawrence, P., Buggerstaff, C., and Grubb, T. (1985). Factors of stress among police officers. Crim. Just. Behav. 12, 111-128.

White, M. D., Cooper, J. A., Saunders, J., and Raganella, A. J. (2010). Motivations for becoming a police officer: re-assessing officer attitudes and job satisfaction after six years on the street. J. Crim. Just. 38, 520-530. doi: 10.1016/j.jcrimjus. 2010.04.022
Wickramasinghe, N. D., and Wijesinghe, P. R. (2018). Burnout subtypes and associated factors among police officers in Sri Lanka: a cross-sectional study. J. Forensic Legal Med. 58, 192-198. doi: 10.1016/j.jflm.2018.07.006

Wirth, M. D., Andrew, M. E., Burchfiel, C. M., Burch, J. B., Fekedulegn, D., Hartley, T. A., et al. (2017). Association of shiftwork and immune cells among police officers from the Buffalo Cardio-metabolic occupational police stress study. Chronobiol. Int. 34, 721-731. doi: 10.1080/07420528.2017.1316732

Wray, C. A., and Jarrett, S. B. (2019). The relationship between burnout and suicidal ideations among Jamaican police officers. Int. J. Police Sci. Manag. 21, 181-189. doi: 10.1177/1461355719856026

Zukauskas, G., Burba, B., Rukšenas, O., Grigaliuniene, V., and Mitchell, J. T. (2009). A study of stress affecting police officers in Lithuania. Int. J. Emerg. Ment. Health $11,205-214$.

Zulkafaly, F., Kamaruddin, K., and Hassan, N. H. (2017). Coping strategies and job stress in policing: a literature review. Int. J. Acad. Res. Bus. Soc. Sci. 7, 458-467. doi: 10.6007/IJARBSS/v7-i3/2749

Conflict of Interest: The authors declare that the research was conducted in the absence of any commercial or financial relationships that could be construed as a potential conflict of interest.

Copyright (c) 2020 Queirós, Passos, Bártolo, Marques, da Silva and Pereira. This is an open-access article distributed under the terms of the Creative Commons Attribution License (CC BY). The use, distribution or reproduction in other forums is permitted, provided the original author(s) and the copyright owner(s) are credited and that the original publication in this journal is cited, in accordance with accepted academic practice. No use, distribution or reproduction is permitted which does not comply with these terms. 